University of Pennsylvania Carey Law School

Penn Law: Legal Scholarship Repository

Faculty Scholarship at Penn Law

2001

\title{
Assessing the Advocacy of Negotiated Rulemaking: A Response to Philip Harter
}

Cary Coglianese

University of Pennsylvania Carey Law School

Follow this and additional works at: https://scholarship.law.upenn.edu/faculty_scholarship

Part of the Administrative Law Commons, Dispute Resolution and Arbitration Commons, Law and Economics Commons, Litigation Commons, Policy Design, Analysis, and Evaluation Commons, and the Public Administration Commons

\section{Repository Citation}

Coglianese, Cary, "Assessing the Advocacy of Negotiated Rulemaking: A Response to Philip Harter" (2001). Faculty Scholarship at Penn Law. 1334.

https://scholarship.law.upenn.edu/faculty_scholarship/1334

This Article is brought to you for free and open access by Penn Law: Legal Scholarship Repository. It has been accepted for inclusion in Faculty Scholarship at Penn Law by an authorized administrator of Penn Law: Legal Scholarship Repository. For more information, please contact PennlawIR@law.upenn.edu. 


\section{ASSESSING THE ADVOCACY OF \\ NEGOTIATED RULEMAKING: \\ A RESPONSE TO PHILIP HARTER}

\section{Cary Coglianese*}

For many years, advocates of negotiated rulemaking have made enthusiastic claims about how negotiated rulemaking would "break impasses," "cure malaise," and "bypass lawyers" in the administrative process. ${ }^{1}$ Strikingly, such advocates have expressed little interest over the years in systematically testing their claims by assessing the effectiveness of negotiated rulemaking against existing rulemaking processes. My research, in contrast, aims to do just that. Beginning several years ago, I set forth to test the widely stated claims about the superiority of negotiated rulemaking for preventing litigation and saving time in the regulatory process. ${ }^{2}$ Following exacting and transparent standards of empirical evaluation, my research demonstrates all too clearly that negotiated rulemaking has failed to meet these two prominent goals. It neither saves time nor reduces litigation. ${ }^{3}$

* Associate Professor of Public Policy, Harvard University, John F. Kennedy School of Government; Chair of the Regulatory Policy Program, Center for Business and Government; and Affiliated Scholar, Harvard Law School. The preparation of this response was supported in part by the Savitz Family Fund for Environment and Natural Resources Policy at the Kennedy School of Government. I am grateful for research assistance from Curt James and Matthew Salloway, and for helpful comments from Steven Balla, Derek Bok, Tom Burke, Jane Fountain, David Hart, David Lazer, and Jennifer Nash.

1 See, e.g., Lawrence Susskind \& Jeffrey Cruikshank, Breaking The Impasse: Consensual Approaches to Resolving Public Disputes (1987); Philip J. Harter, Negotiating Regulations: A Cure for Malaise, 71 GEO. L.J. 1 (1982) [hereinafter Harter, Cure for Malaise]; Lawrence Susskind \& Laura Van Dam, Squaring Off at the Table, Not in the Courts, TECH. REv., July 1986, at 36; William H. Miller, Bypassing the Lawyers: "Regulatory Negotiation" Gets Test in Agencies, Indus. WK., June 23, 1986, at 20.

2 Cary Coglianese, Assessing Consensus: The Promise and Performance of Negotiated Rulemaking, 46 Duke L.J. 1255, 1259 (1997) [hereinafter Coglianese, Assessing Consensus]. See also Cary Coglianese, Is Consensus an Appropriate Basis for Regulatory Policy?, in ENVIRONMENTAL CONTRACTs: Comparative Approaches to Regulatory InNOVAtion in the United StATES AND Europe 93 (Eric Orts \& Kurt Deketelaere eds., 2001) [hereinafter Coglianese, Is Consensus Appropriate?].

3 Coglianese, Assessing Consensus, supra note 2, at 1278-1309. 
In an essay published in the previous issue of this journal, Philip Harter, a seasoned mediator and longtime advocate of negotiated rulemaking, ${ }^{4}$ offers a critical response to my research, asserting that negotiated rulemaking "has been remarkably successful in fulfilling its promise." 5 While it is perhaps predictable that Harter would continue to advocate for negotiated rulemaking, his response to my research fails to meet ordinary, neutral standards for empirical social science. He repeatedly interprets data to favor negotiated rulemaking. ${ }^{6}$ This may well be understandable as a form of advocacy, but it does not satisfy appropriate standards for making sound empirical judgments. ${ }^{7}$ Harter makes unfounded assertions about my study, disregards basic principles of empirical analysis, and continues to advance bold claims for negotiated rulemaking unsupported by reliable empirical analysis. ${ }^{8}$ In short, Harter is simply wrong about each of the

${ }^{4}$ In 1982, Harter authored a widely-cited article advocating negotiated rulemaking. Harter, Cure for Malaise, supra note 1. This work formed the basis for the Administrative Conference of the United States recommendation in favor of negotiated rulemaking. Recommendation 82-4, Procedures for Negotiating Proposed Regulations, 1 C.F.R. $\$ 305.82-4$ [hereinafter ACUS, Procedures for Negotiating], reprinted in ADMinISTRATIVE CONFERENCE of THE Unted States, Negotiated Rulemaking Sourcebook 11 (David M. Pritzker \& Deborah S. Daiton eds., 1995) [hereinafter ACUS, 1995 SOURCEBOOK]. Harter has since served as a convenor and facilitator in numerous negotiated rulemakings, authored other articles advocating the process, and testified before Congress in favor of its expanded use.

5 Philip J. Harter, Assessing the Assessors: The Actual Performance of Negotiated Rulemaking, 9 N.Y.U. ENvTL LJ. 32, 33 (2000) [hereinafter Harter, Assessing the Assessors]. Harter previously published similar criticisms of my research. Philip Harter, Fear of Commitment: An Affiction of Adolescents, 46 Duke L.J. 1389, 1421-22 \& 1422 n.117 (1997) [hereinafter Harter, Fear of Commitment].

6 This is, of course, not the first time Harter has presented an unbalanced account of negotiated rulemaking. In his original 113-page article advocating negotiated rulemaking in 1982, Harter devoted less than two pages to a consideration of "possible adverse consequences" of negotiated rulemaking, dismissing any fears about such potential drawbacks as "exaggerated." Harter, Cure for Malaise, supra note 1, at 110-12 (emphasis added).

7 It may also, of course, be understandable as a matter of ordinary psychology. See Richard Nisbett \& Lee Ross, Human Inference: Strategies AND SHORTCOMINGS OF Social Judgment 192 (1980) (noting the tendency of individuals to adhere to their beliefs "well beyond the point at which logical and evidential considerations can sustain them" and to apply "asymmetric critical standards to supportive and opposing evidence").

${ }^{8}$ Each of these problems is discussed in the subsequent Parts of this Article. To pick one example of the last of these problems, Harter concludes in his recent article that "[r]eg-neg has proven to be an enormously powerful tool in addressing highly complex, politicized rules, the very kind that stall agencies 
many criticisms he levels against my research. Not one of his claims undercuts my original findings in any way.

Although Harter's criticisms are without merit, they deserve a response for the same reason that negotiated rulemaking and other administrative innovations need evaluation in the first place: negotiated rulemaking places significant new demands on those inside and outside of government and it can present potentially significant obstacles to the development of sound public policy. ${ }^{9}$ Before recommending that agencies increase their reliance on negotiated rulemaking, it only makes sense to assess whether this alternative procedure has achieved its goals and made any demonstrable improvement over existing regulatory practices. ${ }^{10}$ In the absence of careful, systematic research, conscientious agency officials have no reliable way to evaluate negotiation advocates' claims and to determine whether one set of procedures performs better than the alternatives. ${ }^{11}$

when traditional or conventional procedures are used." Harter, Assessing the Assessors, supra note 5, at 56. As support, Harter simply cites an interview with another long-standing advocate of negotiated rulemaking. Id. at $56 \mathrm{n} .117$ (citing interview with Neil Eisner of the Department of Transportation). Other negotiation professionals have rightfully disparaged such use of "advocacy science," by which those whose interests are affected by scientific research resort to "smokescreen" and "slash and burn" tactics to challenge the studies they find adverse and to promote alternative studies that would seem to support their interests. See, e.g., Lawrence Susskind \& Patrick Field, Dealing with an Angry Public: The Mutual Gains Approach to Resolving Disputes 8. 12 (1996) (discussing "smokescreen" and "slash and burn" public relations ploys); Susskind \& Van Dam, supra note 1, at 38 (complaining that "Advocacy science ... [is] eroding the credibility of all scientific testimony in public disputes.").

9 See, e.g., Coglianese, Is Consensus Appropriate?, supra note 2, at 106-13; Michael McCloskey, Problems with Using Collaboration to Shape Environmental Public Policy, 34 Val. U. L. Rev. 423, 434 (2000) (arguing that consensusbuilding "is a cumbersome process that is plagued by disadvantages that outweigh[] its perceived advantages.").

10 In this way, careful attention to the impact of negotiated rulemaking on its prominent goals of preventing litigation and saving time in the regulatory process is consistent with the principles underlying the Government Performance and Results Act of 1993, Pub. L. 103-62, 107 Stat. 285 (codified as amended in scattered sections of 5 U.S.C. \& 39 U.S.C.) (promoting agency evaluation of the results of government programs).

11 As Neil Kerwin has observed, "[t]he purported superiority of consensual processes over decisionmaking techniques that employ methods outlined in the APA ... cannot be established by mere positing of generalities and abstractions." Cornelius M. Kerwin, Assessing the Effects of Consensual Processes in Regulatory Programs: Methodological and Policy Issues, 32 AM. U. L. Rev. 401, 409 (1983). 
This Article proceeds to show why Harter's criticisms miss their target and fail to weaken my original findings. In Part I, I provide a summary of my original research and briefly review some elementary principles of research that apply to any empirical evaluation. Since negotiated rulemaking has long been advertised as a "cure" for regulatory ills, its effectiveness should be evaluated as neutrally as any potential cure for illness should be evaluated. The remaining parts of this Article are organized around the three principal arguments Harter advances. He criticizes the way I measure the length of the rulemaking process, claims that I fail to appreciate differences in litigation, and suggests that, in any case, my results do not matter since negotiated rulemaking achieves demonstrably better rules than existing regulatory practices. In Part II, I reply to Harter's criticisms of my measure of the duration of negotiated rulemakings, explaining in particular why it is entirely appropriate to include EPA's farmworker protection rule in a study of negotiated rulemaking. In Part III, I show how Harter is similarly mistaken in his criticisms of my analysis of negotiated rulemaking and litigation. In Part IV, I respond to Harter's claim that negotiated rulemaking has resulted in better rules, explaining why there is no more evidence to support this claim than there is to support claims that negotiated rulemaking would save time and avoid litigation.

The absence of support for Harter's criticisms, like the absence of empirical support for the many years' worth of enthusiastic claims made for negotiated rulemaking, serves only to underscore the conclusion of my original research. The promises made for negotiated rulemaking remain unfulfilled.

\section{I}

Is Negotiated Rulemaking a "Cure"?

In his original 1982 article on negotiated rulemaking, Philip Harter advocated negotiated rulemaking as a cure for " $[t]$ he malaise of administrative law, which has marched steadily toward reliance on the judiciary to settle disputes and away from direct participation of affected parties."12 He decried the time and expense of administrative rulemaking under conventional procedures, observing that:

12 Harter, Cure for Malaise, supra note 1, at 113. 
We have grown accustomed to rulemaking procedures that take several years to complete at the agency level and, in the event judicial review is sought, another year or two in the courts. The cost of participating in such a proceeding for both the agency and the private parties can be staggeringly high..$^{13}$

For Harter, negotiated rulemaking provided an alternative that would "reduce the time and cost of developing regulations." 14 $\mathrm{He}$ argued that it offered agencies an antidote to "the traditional battle" of conventional rulemaking. ${ }^{15}$

In negotiated rulemaking, a negotiation process takes place before an agency issues a proposed regulation. ${ }^{16}$ The agency

13 Id. at 21. See also id. at 6 (noting that "the malaise remains-parties complain about the time, expense, and legitimacy of the administrative decisions reached by the hybrid [notice-and-comment rulemaking] process") (footnotes omitted).

14 Id. at 30.

$15 \mathrm{Id}$. at 112.

16 The process is outlined in the Negotiated Rulemaking Act of 1990, 5 U.S.C. $\$ \S 561-570$ (1994 \& Supp. V 2000), which was re-authorized by the Administrative Dispute Resolution Act of 1996, Pub. L. No. 104-320, § 11, 110 Stat. 3870, 3873-74 (codified at 5 U.S.C. § 561 (Supp. III 1997)). Negotiated rulemaking is sometimes referred to as "regulatory negotiation," or "reg neg" for short, but the term "regulatory negotiation" actually connotes a broader range of processes of public participation. Harter disputes this distinction, which I stipulated in Assessing Consensus, between regulatory negotiation and negotiated rulemaking. Harter, Assessing the Assessors, supra note 5, at 33 n.1, citing Coglianese, Assessing Consensus, supra note 2, at 1256 n.6. Harter suggests the two terms are synonymous, but in fact they are not. "Negotiated rulemaking" has a clearly defined meaning under federal law, 5 U.S.C. $\$ 562$, while the term "regulatory negotiation" does not. In my many conversations with agency officials and representatives from industry and environmental groups, I have found the term "regulatory negotiation" used quite loosely to refer to any number of forums in which agency officials engage members of the public, not all of which are technically "negotiated rulemakings." This usage may well stem in part from the fact that "negotiated rulemaking" and "regulatory negotiation" have long been treated as conceptually distinct, contrary to Harter's suggestion. See, e.g., Henry H. Perritt, Jr., Negotiated Rulemaking Before Federal Agencies: Evaluation of Recommendations by the Administrative Conference of the United States, 74 GEO. L.J. 1625, 1630 n.13 (1986) (" Regulatory negotiation' refers to use of negotiation in any decisionmaking process by an administrative agency. 'Negotiated rulemaking' is a specific application of regulatory negotiation, the use of negotiation in the rulemaking process."). Indeed, in his 1982 article on negotiated rulemaking, Harter made a similar distinction between what he called sequential "regulatory negotiation," consisting of individual meetings between agency staff and interest group representatives, and the collective, consensus-based negotiations that are characteristic of negotiated rulemaking. Harter, Cure for Malaise, supra note 1, at 32-33. Harter again acknowledges, albeit tacitly, a distinction between "regulatory negotiation" and "negotiated rulemaking" in his recent article criticizing my rescarch. 
convenes a committee comprised of representatives from regulated firms, trade associations, citizen groups, and other affected organizations, as well as members of the agency staff. ${ }^{17}$ The committee meets publicly to negotiate a proposed rule. If the committee reaches consensus, defined as a unanimous concurrence of all the interests, the agency uses the agreement as a basis for its proposed rule and then proceeds according to the notice-andcomment provisions of the Administrative Procedure Act. ${ }^{18}$

Harter's 1982 article proved instrumental in garnering support for negotiated rulemaking as an alternative to conventional rulemaking. The article was based on a report to the Administrative Conference of the United States (ACUS), which then formed the basis for ACUS's recommendation that federal agencies pursue negotiated rulemaking. ${ }^{19}$ The initial ACUS recommendation noted that under the existing form of notice-andcomment rulemaking, "[l]ong periods of delay result, and participation in rulemaking proceedings can become needlessly expensive."20 ACUS's recommendation was premised on the expectation that negotiated rulemaking would overcome the delays, litigation, and other adverse consequences associated with conventional rulemaking and would result in rules more acceptable to the interests affected by agency decisions. ${ }^{21}$

In the years following Harter's article and ACUS's recommendation, agencies began to experiment with negotiated rulemaking and Congress began to consider legislation to provide clear authorization for its use. ${ }^{22}$ Legislative debate in Congress, along with extensive commentary by academics and practitioners, emphasized that negotiated rulemaking would help

There Harter notes that the Grand Canyon visibility rule promulgated in the early 1990s resulted from a "negotiation" which, as he and I agree, was not technically a "negotiated rulemaking." Harter, Assessing the Assessors, supra note 5 , at 50 . The only way to claim that a regulation resulted from negotiations that were not part of a negotiated rulemaking is to recognize, as I did in Assessing Consensus, that "regulatory negotiation" and "negotiated rulemaking" are not fully synonymous.

17 See Negotiated Rulemaking Act, 5 U.S.C. \$§ 564-565.

18 For the Negotiated Rulemaking Act's definition of consensus, see $\S 562(2)$. For the notice-and-comment rulemaking procedures outlined in the Administrative Procedure Act, see 5 U.S.C. $\$ 553$ (1994).

19 ACUS, Procedures for Negotiating, supra note 4, at 11.

$20 I d$.

$21 \mathrm{Id}$.

22 For a detailed review of the legislative debate and commentary, see Coglianese, Assessing Consensus, supra note 2, at 1263-66. 
reduce the delays and litigation that were thought to dominate the conventional rulemaking process. ${ }^{23}$ In the years leading up to the passage of the Negotiated Rulemaking Act of $1990,{ }^{24}$ regulatory negotiation was consistently advocated as a means of improving what was thought to be a time-consuming, litigationprone regulatory process.

From 1983, when the Federal Aviation Administration (FAA) initiated the first federal negotiated rulemaking, ${ }^{25}$ to 1996, the year the Negotiated Rulemaking Act was permanently reauthorized, ${ }^{26}$ about a dozen federal agencies used the procedure to develop and issue at least one rule. All told, federal agencies had completed thirty-five rules using negotiated rulemaking, a number that amounted to less than $0.01 \%$ of all rules issued during the same period. 27 As of 1996, EPA had completed twelve negotiated rulemakings, ${ }^{28}$ more than any other agency. Interestingly, EPA has not initiated any new negotiated rulemaking since 1993. The Department of Transportation and

23 See id. at 1262-71, 1343 app. D.

24 See supra note 16.

25 Administrative Conference of the United States, Negotiated Rulemaking Sourcebook 8 (David M. Pritzker \& Deborah S. Dalton eds., 1990) [hereinafter ACUS, 1990 SOURCEBOOK].

26 See supra note 16.

27 See Coglianese, Assessing Consensus, supra note 2, at 1276-77.

28 National Emissions Standards for Coke Oven Batteries, 58 Fed. Reg. 57,898 (Oct. 27, 1993) (to be codified at 40 C.F.R. pts. 9 \& 63); Wood Furniture Manufacturing Regulations, 60 Fed. Reg. 62,930 (Dec. 7, 1995) (to be codified at 40 C.F.R. pts. 9 \& 63); New Source Performance Standards for Residential Wood Heaters, 53 Fed. Reg. 5860 (Feb. 26, 1988) (to be codified at 40 C.F.R. pt. 60); National Emissions Standards for Hazardous Air Pollutants for Organic Chemicals/Control of Volatile Organic Chemical Equipment Leaks, 59 Fed. Reg. 19,402 (Apr. 22, 1994) (to be codified at 40 C.F.R. pt. 63); Standards for Reformulated and Conventional Gasoline, 59 Fed. Reg. 7716 (Feb. 16, 1994) (to be codified at 40 C.F.R. pt. 80); Permit Modifications for Hazardous Waste Management Facilities, 53 Fed. Reg. 37,912 (Sept. 28, 1988) (to be codified at 40 C.F.R. pts. 124, 264, 265, \& 270); Underground Injection of Hazardous Wastes, 53 Fed. Reg. 28,118 (July 26, 1988) (to be codified at 40 C.F.R. pts. 124, 144, 146, and 148); Disinfectant Byproducts in Drinking Water Information Collection Rule, 61 Fed. Reg. 24,354 (May 14, 1996) (to be codified at 40 C.F.R. pt. 141); Worker Protection for Agricultural Pesticides, 57 Fed. Reg. 38,102 (Aug. 21, 1992) (to be codified at 40 C.F.R. pts. 156 \& 170); Emergency Pesticide Exemptions, 51 Fed. Reg. 1896 (Jan. 15, 1986) (to be codified at 40 C.F.R. pt. 166); Asbestos-Containing Materials in Schools, 52 Fed. Reg. 41,826 (Oct. 30, 1987) (to be codified at 40 C.F.R. pt. 763); Nonconformance Penalties for Heavy-Duty Engines and Heavy-Duty Vehicles Under the Clean Air Act, 50 Fed. Reg. 35,374 (Aug. 30, 1985). 
the Department of Education have also been among the most frequent users of negotiated rulemaking. ${ }^{29}$

Has the use of negotiated rulemaking "cured" the malaise of administrative law? To evaluate whether negotiated rulemaking has had its intended impact, it is helpful to conceive of agencies' use of negotiated rulemaking as an experiment. This is, after all, exactly how Harter and officials at ACUS described negotiated rulemaking when they first recommended its use..$^{30}$ Of course, like most procedural and policy innovations, negotiated rulemaking has not been employed by agencies in a way that permits researchers to evaluate its impact through pure experimental methods. ${ }^{31}$ Agencies have not, for instance, selected rules for negotiation randomly from among all of an agency's rules, but instead have tended deliberately to select rules for negotiation only after concluding that the rule stands a reasonable likelihood of successful negotiation. ${ }^{32}$ Although a true experimental method

29 The Department of Transportation had promulgated seven negotiated rules: Flight Time Limitations and Rest Requirements, 50 Fed. Reg. 29,306 (July 18, 1985) (to be codified at 14 C.F.R. pts. 121 \& 135); Nondiscrimination on the Basis of Handicap in Air Travel, 55 Fed. Reg. 8008 (Mar. 6, 1990) (to be codified at 14 C.F.R. pt. 382); Uniform System for Handicapped Parking, 56 Fed. Reg. 10,328 (Mar. 11, 1991) (to be codified at 23 C.F.R. pt. 1235); Drawbridge Operations, Chicago River, 60 Fed. Reg. 52,298 (Oct. 6, 1995) (to be codified at 33 C.F.R. pt. 117); Roadway Worker Protection, 61 Fed. Reg. 65,959 (Dec. 16, 1996) (to be codified at 40 C.F.R. pt. 214); Transportation for Individuals with Disabilities, 56 Fed. Reg. 45,584 (Sept. 6, 1991) (to be codified at 49 C.F.R. pts. 27, 37 \& 38); Oil Spill Vessel Response Plans, 61 Fed. Reg. 1052 (proposed Jan. 12, 1996) (to be codified at 33 C.F.R. pt. 155). The Department of Education had promulgated six negotiated rules: Financial Assistance to Meet Special Educational Needs of Children, 54 Fed. Reg. 21,752 (May 19, 1989) (to be codified at 34 C.F.R. pts. 75-78, 200 \& 204); Helping Disadvantaged Children Meet High Standards, 60 Fed. Reg. 34,800 (July 3, 1995) (to be codified at 34 C.F.R. pts. 200, 201, 203, $205 \&$ 212); State Vocational and Applied Technology Education Programs, 57 Fed. Reg. 36,720 (Aug. 14, 1992) (to be codified at 34 C.F.R. pts. 400-428); Guaranty Agency Reserve Regulations, 59 Fed. Reg. 60,688 (Nov. 25, 1994) (to be codified at 34 C.F.R. pt. 682); Direct Student Loan Regulations, 59 Fed. Reg. 61,664 (Dec. 1, 1994) (to be codified at 34 C.F.R. pt. 685); Higher Education Amendments of 1992, 59 Fed. Reg. 22,348 (Apr. 29, 1994) (to be codified at 34 C.F.R. pts. 668, 682, \& 690).

30 Harter, Cure for Malaise, supra note 1, at 113; ACUS, Procedures for Negotiating, supra note 4, at 12.

31 For a discussion of program evaluation research designs, see LAWRENCE B. Mohr, Impact Analysis for Program Evaluation (2d ed. 1995).

32 The Negotiated Rulemaking Act requires that, in determining if there is a need to establish a negotiated rulemaking, agencies consider whether "there is a reasonable likelihood that a committee will reach a consensus." 5 U.S.C. $\S 563(a)(4)$ (1994). The criteria specified in the Act and by negotiation consultants for selecting rules for negotiation favor the selection of rules that are more 
is not possible given the nonrandom selection of rules for negotiation, careful social science research still aims to adhere to the basic principles used in an experimental research design as much as possible. Since negotiated rulemaking is thought to be a treatment or a "cure" for the delays and litigation generated by the normal rulemaking process, the appropriate way to evaluate its impact is to compare the outcomes of rules that have been treated with negotiation with the outcomes of a comparison group of similar rules that have not had the negotiation treatment. This comparison group permits researchers to make an inference about the counterfactual, or about what would have occurred in the treatment group absent the application of the negotiation process.

In comparing the outcomes of rules in the treatment group with rules in the comparison group, social scientists adhere to a number of exacting standards to ensure that their research results are sound. ${ }^{33}$ In assessing the recent claims made by Harter, three fundamental principles for neutral empirical analysis are important to keep in mind. First, researchers need to develop and apply clear criteria for determining what constitutes a treatment and how to measure outcomes. ${ }^{34}$ Social scientists call this the process of "operationalizing" key variables and collecting reliable data on them. ${ }^{35}$ The measurement of a rulemaking's duration, for example, should follow a clear standard. Otherwise, measurements become difficult, if not impossible, to interpret and replicate.

Second, researchers should strive to apply the same criteria and analysis to both the treatment group (negotiated rulemaking) and the comparison group (conventional rulemaking). ${ }^{36}$

likely to be resolved from the outset. See Coglianese, Assessing Consensus, supra note 2, at 1317-21.

33 See, e.g., Gary King et al., Designing Social Inquiry: Scientific INFERENCE IN QUALITATIVE RESEARCH (1994); MOHR, supra note 31; DoNALD T. Campbell \& Julian C. Stanley, Experimental and Quasi-Experimen. tal Designs for Research (1963); Carol H. Weiss, Evaluation: Methods For Studying Programs and Policies (2d ed. 1998).

34 See, e.g., KING ET AL., supra note 33, at 25 (stressing the importance of ensuring "that data-collection methods are reliable" so that "applying the same procedure in the same way will always produce the same measure").

35 See, e.g., Jarol B. Manheim \& Richard C. Rich, Empirical Political Analysis: Research Methods in Political Science 57 (4th ed. 1995).

36 See, e.g., KING ET AL., supra note 33, at 25 (emphasizing the importance of consistent data collection efforts to ensure data reliability); WEISS, supra note 33, at 150 (noting the need for careful definition and conceptualization of 
Since the analysis aims to compare the outcomes of both groups, it is important that analysts try to measure the same outcomes consistently across both groups. To do otherwise would be like having election officials in a contested election apply one rule when interpreting votes on ballots favoring one party and a different rule when interpreting votes on ballots favoring the other party.

Finally, it is essential to include in any impact analysis those cases where the treatment failed.37 Just as it would be obviously tautological to conclude that a medicinal cure was effective after examining only the cases where the medicine appeared to work, so too would it be mistaken to declare the success of negotiated rulemaking without considering the cases where it failed. We can only know how well a treatment works if we study all the cases in which it has been applied or tried. In the case of negotiated rulemaking-just as with medications-the treatment sometimes fails. Even if a consensus is not reached, the attempted negotiation must still be analyzed and included in the treatment group for the purpose of assessing the effectiveness of the negotiation process.

Harter and other advocates of negotiated rulemaking have not adhered to these rudiments of empirical research and have written favorably about negotiated rulemaking without making careful, explicit comparisons between its outcomes and the outcomes of conventional rulemaking. At the time the Negotiated Rulemaking Act was re-authorized in 1996,38 the evidentiary basis on which to draw conclusions about the success of the procedure was at best extremely thin. Only a few minor efforts existed that compared the results of negotiated rulemaking directly with the results of conventional rulemaking. ${ }^{39}$ In the first such effort,

measures used in empirical evaluation); PETER H. ROSSI ET AL., Evaluation: A Systematic APPROACH 250 (6th ed. 1999) (explaining that valid measurements must be internally consistent).

37 See, e.g., KING ET AL, supra note 33, at 108-109, 129-32 (discussing the need to ensure variation in the dependent variable); Míchael Q. Patton, Qualitative Evaluation and Research Methods 463-64 (2d ed. 1990) (emphasizing the need to consider "negative cases" in evaluations).

38 See supra note 16.

39 Case studies of negotiated rulemaking did exist. See Coglianese, Assessing Consensus, supra note 2, at 1258 n.17. Typically these individual case studies assumed that the appropriate comparison group for negotiated rulemaking was a highly contentious, lengthy regulatory process, but no explicit effort was made to compare negotiated rulemaking systematically with conventional 
Neil Kerwin and Scott Furlong conducted a study of the duration of EPA rulemakings in which they briefly mentioned that they compared the duration of the four negotiated rules in their sample with the duration of the larger sample of 150 of the most significant EPA rules completed through the conventional rulemaking process. ${ }^{40}$ Using dates from EPA's internal regulatory management system as their basis for operationalizing the duration of rulemaking, Kerwin and Furlong found that, on average, the four negotiated rules went through the entire rulemaking process about eleven months faster than did the average conventional rule in their sample. ${ }^{41}$

A second effort to compare the outcomes of negotiated and conventional rulemakings could be found in the Clinton Administration's National Performance Review (NPR) report "Improving Regulatory Systems." 42 The NPR report made brief but explicit claims comparing EPA's negotiated rules with its conventional rules in terms of both time and the incidence of litigation. ${ }^{43}$ In addition to citing the time savings reported by the Kerwin and Furlong study, the author of the NPR report stated that at EPA negotiated rulemakings had shortened the rulemaking process by up to eighteen months when compared with conventional rulemaking. ${ }^{44}$ The report also asserted that negotiated rulemaking reduced the litigation rate for EPA rules from around seventy-five to eighty percent to twenty percent for negotiated rules. $^{45}$

rulemaking. Kerwin and Langbein set out to compare the views of participants in negotiated rulemaking with the views of those who filed comments in conventional rulemaking, but by 1996 they had only reported results from their negotiated rulemaking interviews. Cornelius M. Kerwin \& Laura I. Langbein, An Evaluation of Negotiated Rulemaking at the Environmental Protection Agency: Phase I (1995) (unpublished report prepared for ACUS, on file with N.Y.U. Environmental Law Journal) [hereinafter Kerwin \& Langbein, Phase I].

40 See Cornelius M. Kerwin \& Scott R. Furlong, Time and Rulemaking: An Empirical Test of Theory, 2 J. PUB. Admin. Res. \& TheORY 113, 122, 124 (1992).

41 Id. at 124, 134 app. A. However, Kerwin and Furlong report that the median length of negotiated rules was virtually the same as the median length of the overall set of rules examined. Id. at $134 \mathrm{app}$. A.

42 Office of the Vice President, Improving Regulatory Systems: Accompanying Report of the National Performance Review 29 (Sept. 1993).
$43 \mathrm{Id}$. at 31.
44 Id. at $32-33$ n.8.
$45 \mathrm{Id}$. at 32 n.7. 
In my research, I have also taken a comparative approach in evaluating the impact of negotiated rulemaking on the duration of rulemaking and the subsequent incidence of litigation. As I state in Assessing Consensus:

My purpose ... is simply to assess negotiated rulemaking on its own terms, using the standards that have been set for it by those legislators, agency officials, practitioners, and scholars who have advocated its use over the years. The goals of saving time and reducing litigation are by far the most prominent ones invoked in the literature and the legislative history. ${ }^{46}$

My research follows appropriate standards for empirical research and overcomes major limitations of the two prior efforts to make comparative assessments of negotiated rulemaking. Unlike Kerwin and Furlong (who, in faimess, never really set out to evaluate negotiated rulemaking), I include in my assessment all the negotiated rulemakings completed by EPA during the study period. Unlike the NPR report, I rely on primary source data on the filings of suits challenging EPA rules and thus provide an accurate account of litigation filed against both negotiated and conventional rules. By carefully applying empirical research methods, I find that on average it has taken EPA about three years to develop a rule, regardless of whether the agency used negotiated rulemaking or conventional rulemaking procedures. ${ }^{47}$ The median duration is also about the same for negotiated and conventional rules. ${ }^{48}$ Negotiated rulemaking does seem to make a difference when it comes to litigation-however, the difference is in the direction opposite to what has been expected. Negotiated rules are challenged fifty percent of the time, while other comparable, significant EPA rules are challenged only thirty-five percent of the time. 49 These results indicate all too clearly that negotiated rulemaking has failed to accomplish its goals of preventing litigation and saving time. Negotiation simply does not "cure" regulatory malaise.

46 Coglianese, Assessing Consensus, supra note 2, at 1259-60 n.21.

47 Id. at 1283-84. I compared the duration of all of EPA's negotiated rulemakings with the duration Kerwin and Furlong reported for the rules included in their study, which were the most significant fifteen percent of all of EPA's rulemakings (150 rules) issued during their study period. See id. at 1280 n.112, 1313-19.

48 Id. at 1284 n.123.

49 Id. at 1300-1301. 
II

\section{Evaluating the Duration of Negotiated Rulemaking}

Harter disagrees with these findings. He first criticizes how I evaluate negotiated rulemaking's impact on the duration of the regulatory process, arguing that I should exclude from my study one rule that EPA negotiated-the farmworker protection rulebecause its committee failed to reach a consensus. ${ }^{50}$ In a few other cases, he also questions my reliance on the publication of the final rule to mark the completion of the rulemaking process. $^{51}$ In total, Harter criticizes my data with respect to the four EPA negotiated rulemakings that took the agency the longest to complete. As a result, Harter claims that once his modifications to the data are made, the average duration of negotiated rulemakings is shorter than the duration of conventional rulemakings. ${ }^{52} \mathrm{He}$ is correct that the average duration would decline if the longest negotiated rules were to be excluded or their length were to be truncated. $\mathrm{He}$ is wrong, however, to suggest that such modifications should be made. The farmworker protection rule, while a failure in terms of achieving consensus, still represented an earnest effort by the EPA to negotiate the rule and merits inclusion in any evaluation of negotiated rulemaking. ${ }^{53}$ The other modifications Harter urges fail to adhere to the basic precepts of consistency and reliability in empirical analysis. ${ }^{54}$ Moreover, even if one were to be persuaded by Harter's advocacy, his modifications would only affect the average duration of negotiated rulemaking, and not the more appropriate measures of rulemaking time.55 The median duration of negotiated rulemaking remains largely unchanged even after Harter's modifications. ${ }^{56}$ More significantly, whatever one makes of the duration of rules from start to finish, the overall investment of staff time and effort by agencies and outside organizations remains indisputably and significantly greater for negotiated rulemaking.

\footnotetext{
50 Harter, Assessing the Assessors, supra note 5, at 41-42.

51 Id . at 45-49.

52 Id. at 49.

53 See infra Part II.A.

54 See infra Part II.B.

55 See infra text accompanying notes $126-29$ and Part II.C.

56 See infra tbl.1.
} 


\section{A. EPA's Negotiated Rulemaking on Farmworker Protection}

Harter first seeks to exclude from analysis what he calls the "peculiar case" of the farmworker protection rulemaking.57 In 1985 , EPA initiated a negotiated rulemaking process to establish a regulation that would reduce the exposure of agricultural workers to the spray of pesticides. ${ }^{58}$ The agency convened a negotiation committee comprising representatives from farming organizations, farmworker unions, agricultural and forest products trade associations, state and local governments, the U.S. Department of Agriculture, and the EPA. ${ }^{59}$ The committee met as a plenary group on several occasions, established a series of five working groups, and developed and circulated working drafts of a proposed regulation. ${ }^{60}$ As the committee neared completion of a final draft of the proposed rule, the negotiations reached an impasse, ${ }^{61}$ and the representatives from the farmworker organizations decided to end their involvement with the negotiations.".2 The EPA attempted to bring the farmworkers' representatives back into the discussions and continued to meet with the remaining members of the committee. ${ }^{63}$ In the end, however, the agency was unable to secure a meaningful consensus without the involvement of the farmworkers' representatives, whom the agency failed to bring back to the table officially.

Harter claims the farmworker protection rule should be excluded from my analysis of the effectiveness of negotiated rulemaking. ${ }^{64} \mathrm{He}$ asserts that the farmworker protection negotiated rulemaking was "abandoned" by EPA and that the bulk of the time associated with this regulation should not be attributed to negotiated rulemaking because it took place after the negotia-

57 Harter, Assessing the Assessors, supra note 5, at 41.

58 See Intent to Form an Advisory Committee to Negotiate Proposed Farmworker Protection Standards for Agricultural Pesticides, 50 Fed. Reg. 38,030 (Sept. 19, 1985).

59 See Worker Protection Standards for Agricultural Pesticides, 53 Fed. Reg. 25,970, 25,972 (proposed July 8, 1988) (to be codified at 40 C.F.R. pts. $156 \&$ 170).

60 See Worker Protection Standards for Agricultural Pesticides, 53 Fed. Reg. at 25,972-25,973.

61 See Susskind \& FIELD, supra note 8, at 35.

62 See Worker Protection Standards for Agricultural Pesticides, 53 Fed. Reg. at 25,973 .

63 See, e.g., Worker Protection Standards, 53 Fed. Reg. at 25,973; Susskind \& Van Dam, supra note 1, at 44. See also Susskind \& FIELD, supra note 8, at 35.

64 Harter, Assessing the Assessors, supra note 5, at 42. 
tions collapsed.65 Yet what happened in the farmworker protection rulemaking could happen in any negotiated rulemaking. Negotiation does not always yield a consensus, and the mere fact that consensus is not reached is no reason to exclude from evaluation those rules for which the agency otherwise earnestly tried to use negotiation.

If we are to determine whether negotiated rulemaking is effective in achieving its goals, both common sense and conventional empirical research methods dictate that we look at all the cases where the technique was used, not only those cases where it succeeds. Although negotiated rulemakings should be excluded when they were genuinely abandoned, I specifically state in $A s-$ sessing Consensus that by "abandoned" negotiated rulemakings "I do not mean that the participants failed to reach consensus." 66 Rather, in a passage that Harter quotes, ${ }^{67}$ I treat as "abandoned" those rulemakings for which the agency, at some point after publication of an intent to negotiate, either (1) "decided not to commence negotiations," (2) "disbanded the committee before seeking even a limited agreement," or (3) "withdrew the underlying regulatory action altogether." 68 Rulemakings that meet any one of these three criteria are rulemakings for which the agency failed to use the negotiation process earnestly as a means of developing a rule, or for which the agency declared its decision to issue no rule at all. ${ }^{69}$ They are cases where the agency essentially decided to forego altogether the experimental treatment called negotiated rulemaking.

The EPA did commence and earnestly pursue negotiations in the farmworker protection rule. The agency worked diligently and responsibly to seek an agreement in this case, and apparently even came close to doing so. ${ }^{70}$ When problems arose, the agency

65 Id.

66 Coglianese, Assessing Consensus, supra note 2, at 1277 n.98.

67 Harter quotes my full definition of "abandoned" negotiated rulemakings. Harter, Assessing the Assessors, supra note 5, at 39 n.30.

68 Coglianese, Assessing Consensus, supra note 2, at 1274 n.98, 1274 tbl.1.

69 As I have noted before, the fact that agencies have decided to abandon certain rules without earnestly seeking agreement shows that rules are not selected for negotiation randomly. In fact, the selection criteria used by agencies to choose rules for negotiation-and then to pursue those negotiations earnestly-favor precisely those rules that are more likely to succeed in the first place. See id. at 1312.

70 Susskind and Field write that the farmworkers withdrew from the committee "[a]s the final draft approached completion." SuSSKIND \& FIELD, supra 
and the other parties offered to replace the facilitator in an effort to keep the farmworkers' representatives on the committee.71 The EPA continued to hold meetings with the rest of the committee, "hoping that the farmworkers' representatives would return."72 In addition, the EPA reportedly continued to share drafts of the proposed rule with the farmworkers' representatives before the opening of the notice-and-comment period. ${ }^{73}$ EPA did not "abandon" the farmworker protection negoliated rulemaking; rather, one non-governmental interest abandoned the negotiation committee-the committee simply failed to reach a consensus. ${ }^{74}$

EPA did eventually issue a final farmworker protection rule, and in doing so the agency made a point of crediting the negotiation process for having "helped shape the proposed regulation."75 Harter himself suggests that the agency learned much from the negotiation process and that the discussion draft that emerged from the negotiations formed a basis for its final rule. ${ }^{76}$ In making this suggestion, however, Harter essentially concedes that the farmworker protection rule was, after all, a negotiated rulemaking. One cannot consistently treat the rule as a negotiated rulemaking in order to claim credit for some benefits, only

note 8 , at 35 . For further discussion of the extensive negotiations that took place, see Worker Protection Standards for Agricultural Pesticides, 53 Fed. Reg. 25,970, 25,973 (proposed July 8, 1988) (to be codified at 40 C.F.R. pts. 156 \& 170).

71 Susskind \& Van Dam, supra note 1, at 44. Harter was the facilitator of this negotiated rulemaking. See 1995 SourCEBOok, supra note 4, at 388.

72 Susskind \& Van Dam, supra note 1 , at 44.

73 Id.

74 In a Federal Register notice published the following year, EPA described the farmworker protection rulemaking as one of the agency's "successiully conducted" negotiations. Intent to Form an Advisory Committee to Negotiate Regulations Governing Major and Minor Modifications of Resource, 51 Fed. Reg. 25,739, 25,740 (July 16, 1986). As stated in this same notice, "EPA encouraged the [farmworker] group to return, and kept all Committee members fully informed to all developments. The remainder of the committee continued to meet, with some in the absent interest group participating informally. The draft rule produced, while not a consensus package, attempts to balance the concerns of all parties." Intent to Form an Advisory Committee to Negotiate Regulations Governing Major and Minor Modifications of Resource, 51 Fed. Reg. at 25,740.

75 Worker Protection Standards, 53 Fed. Reg. at 25,973.

76 Harter, Assessing the Assessors, supra note 5, at 42 n.47 (citing EPA Pesticide Division staff members as claiming that "the agency learned a huge amount" from the negotiations and "based significant administrative action on that insight"). 
to exclude it when it comes to assessing whether negotiated rulemaking achieves other benefits.

Significantly, no one ever claimed that the farmworker protection rule should be treated as anything but a completed negotiated rulemaking until after my research results were published. Lee Thomas, who served as the EPA Administrator during the negotiations and through the publication of the proposed rule, counted the farmworker protection rule among EPA's negotiated rules. ${ }^{77}$ When the EPA's Office of Policy, Planning and Evaluation set out to assess how well negotiated rulemaking worked, it included the farmworker protection rule in its study. ${ }^{78}$ Indeed, on eight separate occasions, the EPA listed the farmworker protection rule as an example of one of its negotiated rulemaking in the Federal Register. ${ }^{79}$ The rule has appeared in three separate

77 Lee M. Thomas, The Successful Use of Regulatory Negotiation by EPA, Admin. L. NEws, Fall 1987, at 1, 3. In a speech given in 1986, Thomas referred to the farmworker protection rule as one of EPA's "completed" negotiated rulemakings, not as a rulemaking the agency had abandoned:

Recently, we completed our third negotiated rulemaking. This one, dealing with farmworker protection, proved something we knew all along. Negotiations are not easy, and they will not always proceed without trouble....

While the farmworker protection standards negotiation started out with promise, one of the major participants elected to leave the advisory committee before a final package was agreed upon. This is permissible under terms of the negotiation process. While it created a problem for those remaining in the rulemaking exercise, the interest group continued to participate informally. The committee kept the group fully informed of all developments, and provided drafts of the regulatory package as it emerged. ... .

Lee M. Thomas, Remarks at the Third National Conference on Dispute Resolution 9 (May 29, 1986) (transcript on file with author).

78 See Program Evaluation Div., EPA, An Assessment of EPA's Ne. gotiated Rulemaking Activities (1987), reprinted in ACUS, 1995 SOURCEBOOK, supra note 4, at 23, 25.

79 Intent to Form an Advisory Committee to Negotiate Proposed Regulation for Architectural and Industrial Maintenance Coatings Under Section 1873(e) of Clean Air Act as Amended and Announcement of Public Meeting, 57 Fed. Reg. 31,473 (July 16, 1992); Intent to Form an Advisory Committee to Negotiate Guidelines and Proposed Regulations Implementing Clean Fucls Provisions and Announcement of Public Meeting, 56 Fed. Reg. 5167 (Feb. 8, 1991); Underground Injection Control, Class II Wells: Intent to Form an Advisory Committee to Negotiate Amendments to Regulations, 56 Fed. Reg. 4957 (Feb. 7, 1991); $\mathrm{NO}_{\mathrm{x}}$ Emission Reduction Provisions and Announcement of Public Meeting, 56 Fed. Reg. 21,348 (May 8, 1991); Intent to Form an Advisory Committee to Negotiate Recycling of Lead Acid Batteries \& Announcement of Organizational Meeting, 55 Fed. Reg. 52,884 (Dec. 24, 1990); Candidates for Regulatory Negotiation, 53 Fed. Reg. 51,003 (Dec. 19, 1988); Consideration of 
reports issued by ACUS, again listed as one of EPA's negotiated rulemakings. ${ }^{80}$ EPA's Consensus and Dispute Resolution Program has kept its own internal list of EPA negotiated rulemakings, on which the farmworker protection rule can be found. ${ }^{81}$ Finally, the director of the Consensus and Dispute Resolution Program, Chris Kirtz, published an article listing the farmworker protection rule as one of EPA's negotiated rulemakings. $\$ 2$

Interestingly, EPA's internal list of negotiated rulemakings was recently modified to add a sentence to the description of the farmworker protection rulemaking stating that the "negotiation was abandoned." 83 This statement never appeared in three earlier versions of this EPA list of negotiated rulemakings, ${ }^{s+4}$ making it reasonable to wonder why EPA staff would change its descripion in this document more than five years after EPA issued its final rule and more than ten years after the farmworkers reconsidered their involvement in the negotiations. Perhaps part of

Establishing an Advisory Committee to Negotiate Proposed Regulations Implementing the Asbestos Hazard Emergency Response Act of 1986, 52 Fed. Reg. 1377 (Jan. 13, 1987); Intent to Form an Advisory Committee to Negotiate Regulations Governing Major and Minor Modifications of Resource, 51 Fed. Reg. 25,739 (July 16, 1986).

80 ACUS, 1990 SourCEBOoK, supra note 25, 331-32; ACUS, 1995 Sourcebook, supra note 4, at 388; Administrative Conference of the United States, Building Consensus in Agency Rulemiaking: IMpleaient. ING tHe Negotiated Rulemaking ACt 56 (1995) [hereinafter ACUS, Build. ING CONSENSUS].

81 EPA, Negotiated Rulemaking at the Environmental Protection AgenCY 4 (Mar. 1992) (on file with the author); EPA, NEgotiated Ruleniak. ING AT the EnVIRonMental Protection Agency 5 (Oct. 1992) (on file with the author); EPA, Negotiated Rulemaking at the Environiental ProTECTION AGENCY 6 (Nov. 18, 1994) (on file with the author). There is one negotiated rulemaking-on lead acid battery recycling - that was included on these lists but which I reated as "abandoned." That is because it truly" was. The EPA decided, based on its risk and cost analysis, not to issue any rule at all on lead acid battery recycling. See id. at 4-5 (noting that EPA adjourned the committee "after reviewing the risk and cost information [and concluding] that the risk/benefits did not adequately balance the cost of regulating"); Lead-Acid Battery Committee Disbanded by EPA Afier Months of Regulatory Talks, 22 Env't Rep. (BNA) No. 21, at 1339 (Sept. 20, 1991) (noting that EPA terminated the entire rulemaking after "two reports showed that the costs associated with increasing lead acid battery recycling were not justified by the small reduction in risk").

82 Chris Kirtz, Regulatory Negotiation: The New' Way' to Develop Regulations? 1 J. EnvTL PeRMitTING 269, 277 (1992).

83 EPA, Negotiated Rulemaking at the Environmental Protection AgENCY 6 (Jan. 2, 1998) (emphasis added) (on file with the author).

84 See supra note 81. 
the explanation lies in the fact that EPA made a point to distribute copies of its altered list at the 1998 Association of American Law Schools panel organized around my research. ${ }^{85}$ When the farmworker protection proceeding was described earlier by the agency in the Federal Register, EPA never described the negotiated rulemaking as having been "abandoned" (the same word used to label the category of rules excluded from my study). Rather, EPA noted that representatives from four groups "decided to discontinue participation in the Regulatory Negotiation process" and that afterwards the agency still scheduled four additional meetings with the remaining members of the negotiation committee. ${ }^{86}$

Notwithstanding Harter's and EPA's efforts to revise the historical record, the farmworker protection rule is properly considered one of the agency's negotiated rules. Administrative law scholars have considered it as such. ${ }^{87}$ Moreover, Laura Langbein and Neil Kerwin, whose research Harter considers "rigorous" and "the only careful and comprehensive" empirical research on negotiated rulemaking, 88 initially included the farmworker protection rule in their study. ${ }^{89}$ They eventually dropped it from their sample of negotiated rules, but not because of any princi-

85 Chaired by Peter Schuck of Yale Law School, the panel included Philip Harter, Jody Freeman of UCLA, Thomas Kelly, of EPA's Regulatory Management and Information Office, and myself. Kelly has also subsequently criticized my research in terms similar to Harter's. For an exchange with Kelly, sec Thomas E. Kelly, Letters, Questionable Conclusions, Gov'T Execurive, Oct. 1998, available at 1998 WL 10315070; Cary Coglianese, Letters, More on Negotiated Rulemaking, Gov'T EXECuTIVE, Mar. 1999, at 88, available at 1999 WL 11998419.

86 See Worker Protection Standards for Agricultural Pesticides, 53 Fed. Reg. 25,970, 25,973 (proposed July 8, 1988) (to be codified at 40 C.F.R. pts. 156 \& 170). See also supra notes 58-63 and accompanying text. Under the operating protocol for this negotiated rulemaking, the committee members were permitted to discontinue negotiations at any time. See Philip J. Harter, The Role of Courts in Regulatory Negotiation-A Response to Judge Wald, 11 CouUM. J. ENVTL. L. 51, 72 (1986) (reprinting the operating protocol for the farmworker protection negotiated rulemaking).

87 See, e.g., Robert V. Percival, The Bounds of Consent: Consent Decrees, Settlements and Federal Environmental Policy Making, 1987 U. CHr. LEGAL. F., 327, 330 n.10; Perritt, supra note 16, at 1686-87; Sidney A. Shapiro, Lessons from a Public Policy Failure: EPA and Noise Abatement, 19 Ecolooy L.Q. 1, 56 (1992).

88 Harter, Assessing the Assessors, supra note 5, at 55-56.

89 Langbein \& Kerwin, Regulatory Negotiation versus Conventional Rule Making: Claims, Counterclaims, and Empirical Evidence, 10 J. PUв. ADMIN. Res. \& TheORY 599, 600 (2000). 
pled or methodological reason for excluding it from a study of the performance of negotiated rulemaking. Rather, Langbein and Kerwin dropped it simply because they were unable to locate enough of the participants in the rulemaking to interview. ${ }^{90}$ Furthermore, Harter has himself acknowledged that the farmworker protection rulemaking was a negotiated rulemaking, going so far as to reprint the organizational protocol for the negotiations as an appendix to an earlier article..$^{91}$

It is understandable why an advocate would now like to treat the farmworker protection rulemaking as if it were not a negotiated rulemaking for the purpose of determining the average duration of negotiated rules. The farmworker protection rule took longer to complete than any other.92 As Harter points out, removing this one rule from the group of EPA negotiated rulemakings has the effect of decreasing the average duration of these rules by approximately four months. ${ }^{93}$ Yet Harter fails to note that in using Federal Register notices to compute the duration of negotiated rulemakings, I actually understate the average duration by about the same amount of time. As I note in Assessing Consensus, "Federal Register listings yield an average time for the four negotiated rules in the Kenvin and Furlong study of 1.8 years (647 days), more than four months shorter than the average they report for the same rules [778 days]." ${ }^{44}$ My approach therefore underestimates rulemaking duration because it excluded the agency work that precedes the publication of a notice of intent and which leads the agency to make the decision to en-

90 See id. (stating that "[w]e had to drop one negotiated rule because we could not locate enough respondents (Farmworker Protection Standards)"); Kerwin \& Langbein, Phase I, supra note 39, at 5 (noting that "the location efforts were so unsuccessful that the reg neg-farmworker protection-ivas dropped from the original list of nine, reducing it to the current eight").

91 Harter, supra note 86, at 60, 70-72 app.

92 In his critique, Harter states that "if one wants to make much of 'average" time for development, the aberrant nature of [the farmworker protection] case should be noted." Harter, Assessing the Assessors, supra note 5, at 42 . If by this Harter means to suggest that I do not reveal the duration of this rule, he is again mistaken. I distinctly note in Assessing Consensus that the farmworker protection rule was the negotiated rulemaking of longest duration. Coglianese, Assessing Consensus, supra note 2, at 1279.

93 Harter, Assessing the Assessors, supra note 5, at 42. Harter does not indicate that even by excluding this rule the median duration of EPA's negotiated rules decreases by only less than a month: from 777 days to 749 days. For a discussion of the median as a measure of central tendency, see infra text accompanying note 129.

94 Coglianese, Assessing Consensus, supra note 2, at 1282-83. 
gage in a negotiated rulemaking. In this and other ways, my approach relies on conservative measures that in effect create a "deliberate bias in favor of finding a time savings in rules developed with negotiated rulemaking procedures." 95 As a result, even supposing the farmworker protection rule should be excluded as a negotiated rulemaking, the resulting average time decrease caused by excluding it is still within the bounds of what can be explained by the conservative measure I used for the duration of negotiated rulemaking. ${ }^{96}$ It is simply not possible to conclude with any confidence that negotiated rulemaking has made the rulemaking process significantly shorter.

\section{B. Calculating Rulemaking Duration}

Harter critiques my analysis of rulemaking duration in other ways. He claims, for example, that by using a "strictly numerical methodology" for evaluating the duration of rulemaking I have ignored "the varying complexity of rules." 97 He notes that "[r]ulemaking is an inherently political activity" and argues that "counting days between two events disregards all the dynamics of political activity."98 Although Harter never clearly states what inference he thinks should be drawn from these vague points, he appears to be suggesting either (1) that negotiated rulemaking should not be subject to empirical evaluation"9 or (2) that omitted, perhaps even unmeasurable, variables influence the duration of the rulemaking process, making quantitative analysis unreliable. There is no reason to support the first claim that negotiated rulemaking should be exempt from the kind of evaluation to

95 Id. at 1283-84 n.120 (emphasis added).

96 Moreover, if the farmworker protection rule were removed from the set of negotiated rules, this would only serve to increase the overall litigation rate for negotiated rulemakings to fifty-five percent, since the farmworker protection rule was never subjected to a petition for judicial review. Of course, EPA did negotiate the farmworker protection rule, as the agency earnestly sought to obtain an agreement.

97 Harter, Assessing the Assessors, supra note 5, at 45.

98 Id.

99 Cf. Harter, Fear of Commitment, supra note 5, at 1421 (noting his "skepticism over evaluations"). Interestingly, Harter's purported skepticism of evaluations is selective. He draws no issue with the methodology of the Kerwin and Furlong study, supra note 40, which also counted days, nor with that of the Langbein and Kerwin study, supra note 89, which also employed a "numerical methodology" but which Harter considers "enormously helpful," Harter, Fear of Commitment, supra note 5, at 1421. 
which other policies or procedures are normally subjected. ${ }^{100}$ Even advocates of negotiated rulemaking recognize that it should be subject to evaluation. ${ }^{101}$

The second claim raises a concern that should be considered for all empirical research, but it matters only if there is reason to suspect that omitted variables are relevant and systematically biasing the results in one direction. ${ }^{102}$ Harter offers no credible reason to suspect that the so-called "dynamics" inherent to all rulemaking systematically operate to lengthen the time it would otherwise take to complete the rulemakings that were negotiated, nor does he specify any particular variable that should have been included in my analysis. In contrast, I extensively scrutinize the possibility of omitted variable bias in Assessing Consensus. ${ }^{103}$ All the available evidence indicates that the rules selected for negotiation tend to involve underlying issues and interests that made them more-not less-likely to succeed in achieving a timely outcome. ${ }^{104}$ EPA has not used negotiated rulemaking for

100 See supra note 10 and accompanying text. See also ACUS, Procedures for Negotiating, supra note 4, at 11 (noting that negotiated rulemaking "should be reviewed after it has been used a reasonable number of times").

101 See Lawrence Susskind \& Gerard McMahon, The Theory and Practice of Negotiated Rulemaking, 3 YALE J. ON REG. 133, 142 (1985) (noting that the benefits of negotiated rulemaking must be demonstrated). See generally' Kerwin, supra note 11.

102 See, e.g., King et al., supra note 33, at 169 (noting that "we can safely omit control variables, even if they have a strong influence on the dependent variable, as long as they do not vary with the included explanatory variable").

103 Coglianese, Assessing Consensus, supra note 2, at 1313-17. King, Keohane, and Verba "advise that all researchers, quantitative and qualitative, systematically look for omitted control variables and consider whether they should be included in the analysis." KING ET AL, supra note 33, at 172. For precisely this reason, I specifically examined the possibility that the economic impact of the rule (that is, those rules classified as major rules under Executive Orders 12291 and 12866) would affect the analysis, since so-called major rules do tend to take a longer time to develop and are more prone to litigation. I concluded that this variable does not account for my findings since "EPA has not negotiated a disproportionate number of major rules." Coglianese, Assessing Consensus, supra note 2 , at 1313 n.259, 1316. Furthermore, although the number of cases is small, EPA's major negotiated rules took longer to develop than did other EPA major rules and were still challenged at a higher rate than were its major rules overall. Id.

104 Harter asserts that the rules selected for negotiated rulemaking have involved "particularly difficult, contentious issues that have eluded closure by means of traditional rulemaking procedures." Harter, Assessing the Assessors, supra note 5, at 38-39. In contrast, EPA itself has acknowledged that negotiated rulemaking has been selected for "second-tier" rules which address "program implementation-rather than rules establishing program structure." Program 
the rules affecting the broadest number of organizations nor for those rules raising the most contentious policy issues. Rather, the agency has tended to follow the advice of negotiation consultants, as well as the guidelines of the Negotiated Rulemaking Act, to select rules for negotiation for which the agency determines there is a preexisting likelihood of success within a limited amount of time.105 Admittedly, on some occasions the agency has selected significant rulemakings to negotiate and, as we know, it has also sometimes misjudged whether a consensus could be attained in a fixed time period. ${ }^{106}$ Overall, though, the agency has tended to select rules that are expected to take less time to promulgate. ${ }^{107}$

Harter also claims that instead of using a consistent, verifiable method of calculating rulemaking duration, I should have imputed different ending points to negotiated rules based on "the actual, immediate goal the agency hoped to accomplish" and "what those who would be affected by the agency's action thought."108 Harter asserts that because I used the date when the agency published its final rule, rather than imputing ending

Evaluation Division, supra note 78, at 23, 34. EPA's statement of selection criteria for negotiated rulemaking begins by noting that "[i]t is important to screen potential rulemakings to identify instances where negotiation of the rule has a high probability of successful use." EPA Regulatory Negotiation Candi. DATE SELECTION CRITERIA, reprinted in ACUS, 1995 SouRCEBOOK, supra note 4, at 42, 42. See also EPA Regulatory Negotiation Project, 48 Fed. Reg. 7494, 7495 (Feb. 22, 1983) (noting that "it is important to screen potential rulemakings to identify where this approach has a high probability of success"). In Assessing Consensus, I extensively considered the possibility that the rules EPA selected for negotiation were more difficult or contentious at the outset. Coglianese, Assessing Consensus, supra note 2, at 1311-21. My review indicated that while EPA's negotiated rules were generally not trivial ones, neither were they the most significant or conflict-ridden rules promulgated by the agency. Id. at 1318-19.

105 For examples of selection guidelines, see Coglianese, Assessing Consensus, supra note 2, at 1319-20.

106 See supra Part II.A.

107 Coglianese, Assessing Consensus, supra note 2, at 1317-21. See also Steven J. Balla \& John R. Wright, Consensual Rulemaking and the Time It Takes to Develop Rules 25 (1999) (unpublished paper presented at the Fifth National Public Management Conference, College Station, TX, Dec. 3-4, 1999, on file with author) (finding that negotiated rulemaking was used for rules that were relatively easier to resolve); Jeffrey P. Cohn, Clearing the Air, Gov'r Ex. ECUTIVE, Sept. 1, 1997, at 45, 50, available at 1997 WL 9254804 (stating that "most negotiated rule-making involves relatively narrow rules" and usually does not work for "[h]ighly politicized issues, ones with broad national implications or ones that represent new policy directions").

108 Harter, Assessing the Assessors, supra note 5, at 45. 
points for negotiated rulemakings, I fail "[t]o conduct an accurate empirical study of rulemaking." 109 Actually, the danger is just the opposite. If researchers studying the duration of rulemaking were to make their own ad hoc decisions about when a rulemaking begins and ends, their research would lack reliability. ${ }^{110}$ Without clear criteria for collecting data and making measurements, individual researchers would have to make their own decisions about when an agency's rulemakings ended. Such an approach would make it exceedingly difficult, if not impossible, to verify and interpret results across studies. ${ }^{111}$

Thus, it is important for researchers to operationalize rulemaking duration using a consistent, verifiable indicator such as Federal Register notices or other uniform administrative indicators. This is almost certainly the reason that Neil Kerwin and Scott Furlong opted for such an approach, relying on the dates found in EPA's internal regulatory tracking system rather than their own interpretation of when individual rulemakings were completed. ${ }^{112}$ More recently, political scientists John Wright and Steven Balla conducted a further study of the length of negotiated rulemaking-again using the dates of notices in the Federal Register. ${ }^{113}$ Choosing the date on which a final rule is promul-

109 Id. at 46. In suggesting that researchers should use the "actual, immediate goal the agency hoped to accomplish," Harter appears to conceive of adminisrative agencies as unified entities that typically possess a single, discernible goal in a rulemaking. Id. Yet bureaucratic organizations are much more complex, with different actors in an agency possessing different goals. See JAMES Q. WiIson, Bureaucracy: What Government Agencies Do and Why They Do It 27-28 (1989); R. Shep Melnick, Regulation and the Courts: The CAse of the Clean Arr Act 38-43 (1983). Moreover, if Harter were correct that in some cases the agency achieved its actual goal prior to the promulgation of the final rule, then one might well have expected the agency to have promulgated the final rule at that earlier time, or at least as soon after the close of the comment period as possible. That the agency did not do so, and in some cases worked for several more years before issuing a final rule, raises the likelihood that there were other, more nuanced or complicated goals at stake in these cases.

110 See, e.g., KING ET AL, supra note 33, at 25 (stressing the importance of ensuring "that data-collection methods are reliable" so that "applying the same procedure in the same way will alvays produce the same measure").

111 See, e.g., id. at 26-27 (stressing the importance of replicability and urging that "scholars should always record the exact methods, rules, and procedures used to gather information and draw inferences so that another researcher can do the same thing and draw (one hopes) the same conclusion").

112 Kerwin \& Furlong, supra note 40, at 121-22.

113 Balla \& Wright, supra note 107, at 14 (using the time that elapsed between the publication of the proposed rule and the issuance of the final rule). 
gated is particularly appropriate given that this is the point at which the agency has taken a final, legally reviewable action. ${ }^{114}$ Since one of the main goals attributed to negotiated rulemaking is to reduce subsequent litigation over agency rules, it is entirely appropriate to use the publication of the final rule as the ending point of a negotiated rulemaking for purposes of evaluation. Even Langbein and Kerwin, in the study that Harter praises, regard the outcome of the negotiated rulemaking as the promulgation of the final rule. ${ }^{115}$

Moreover, as any administrative lawyer knows, the rulemaking process does not necessarily end once the agency issues a final rule. Even putting aside any subsequent litigation, agencies do revisit their final rules, amend and revise them, and even occasionally rescind them. ${ }^{116}$ Researchers who free themselves from a consistent data collection rule face an extremely wide range of potential starting and ending points for any particular rulemaking. For example, as I note in Assessing Consensus, the negotiated rulemaking over drinking water standards for disinfectant byproducts had, by 1996, resulted in a final rule governing the collection of drinking water information even though the substantive drinking water standards based on the negotiations still remained as proposed rules. ${ }^{117}$ I use the date of the "first final rule to emerge from this negotiated rulemaking process, even though it is an information collection rule and not a drinking water standard" simply to ensure that my estimates are employed consistently and conservatively. ${ }^{118}$ The farmworker protection rule is yet another example of a rulemaking that did not really end with the promulgation of a final rule. As I note in Assessing Consensus, debate over the farmworker protection rule persists: "EPA has issued extensions and changes to the rule,

114 5 U.S.C. $\$ 704$ (1994).

115 Langbein \& Kerwin, supra note 89, at 603.

116 For example, consider, the National Highway Traffic Safety Administration's passenger restraint requirements which the agency rescinded in 1981. See Motor Vehicle Mfrs. Ass'n of Am. v. State Farm Mut. Auto. Ins. Co., 463 U.S. 29, 34-40 (1983) (noting that "the requirement has been imposed, amended, rescinded, reimposed, and now rescinded again" and giving detailed history).

117 Drinking Water Information Collection Rule, 61 Fed. Reg. 24,354 (May 14, 1996) (to be codified at 40 C.F.R. pt. 141); Enhanced Surface Water Treatment Requirements, 59 Fed. Reg. 38,832 (proposed July 29, 1994) (to be codified at 40 C.F.R. 141, 142); Disinfectants and Disinfection Byproducts, 59 Fed. Reg. 38,668 (proposed July 29, 1994) (to be codified at 40 C.F.R. 141, 142).

118 Coglianese, Assessing Consensus, supra note 2, at 1283 n.120. 
Congress has entered the fray, and outside groups have threatened litigation."119 Opening measurement to ad hoc judgments would not only enable some to claim that rulemaking was shorter in some cases, but it would also allow others to claim that rulemaking was still longer in other cases.

The approach I take in my empirical research adheres to sound social science research standards in that it relies on neutral, consistent methods of calculating the duration of rulemaking. Harter's approach, on the other hand, tips the scales in favor of finding a time savings for negotiated rulemaking. He makes adjustments that shorten the process for negotiated rulemaking, but he never acknowledges the need to be consistent and make similar adjustments to the comparison group of rules adopted through conventional notice-and-comment procedures. $120 \mathrm{Har}-$ ter claims, for example, that an earlier ending date should be used for the equipment leaks rule because the EPA issued an early notice of the agreement in the equipment leaks rulemaking "so industry could begin taking actions to comply."121 In an earlier article, Harter notes that many firms "were complying with the rule long before it was in effect."122 He similarly argues that the ending date of the reformulated gasoline rule should be moved up by about eight months because that was the time when the EPA held a series of workshops "so that those affected could

119 Id. at 1279 n.111.

120 Cf. KING ET AL, supra note 33, at 28 (noting that "deliberately" choosing cases that support our theory" is an "obvious example" of biased empirical inference). Harter draws attention, for instance, to the fact that the Coast Guard issued a circular and an interim rule before it promulgated a final rule in the negotiated rulemaking on vessel response plans. Harter, Assessing the Assessors, supra note 5, at 43-44. Although he argues that the agency accomplished its goals by issuing these interim documents, the fact is that the Coast Guard still made significant modifications before promulgating the final rule, indicating that the agency had not in fact satisfied all its goals. See Vessel Response Plans, 61 Fed. Reg. 1052 (Jan. 12, 1996) (discussing substantive changes made to interim rule). More significantly, even assuming that an interim rule were a meaningful end point for a rulemaking that generates a subsequent final rule, one would need to recognize that the issuance of interim rules is not uncommon in current conventional rulemaking practices. See, e.g., Michael Asimow, Interim-Final Rules: Making Haste Slowly, 51 AdMIN. L. Rev. 703, 712-15 (1999) (documenting the increasing use of interim rules by administrative agencies). To be consistent, analysts need to make similar judgments about the ending points for conventional rulemaking processes, which with some frequency include the issuance of interim guidances along the way to a final rule. Harter does not do this.

121 Harter, Assessing the Assessors, supra note 5, at 46.

122 Harter, Fear of Commitment, supra note 5, 1427 app. B. 
comply." 123 Yet what Harter fails to acknowledge is that regulated entities often take steps to comply with looming environmental regulations well in advance of agency rules coming into effect. In many corporations and trade associations, lawyers and managers regularly work to anticipate the EPA's regulatory agenda, taking steps to bring their organizations and members into compliance before the final rules take effect. ${ }^{124}$ This is especially the case with regard to regulations affecting equipment or production processes, as compliance can require significant capital expenditures and lead time for planning. It is in firms' interests to avoid the risk of business interruption or regulatory liability, so firms often plan ahead and begin taking steps to comply after an agency issues a proposed or interim rule or otherwise signals its regulatory direction. ${ }^{125}$

Overall, Harter presents his data in such a way as to favor negotiated rulemaking. He argues that if one negotiated rule is excluded from study, and if the duration of two other rules is shortened, the average duration of the EPA's negotiated rulemakings is only 751 days instead of 1,013 days, or thirty-five percent shorter than the average duration reported in my study. ${ }^{126}$ This reduction in average duration arises because the

123 Harter, Assessing the Assessors, supra note 5, at 48.

124 See, e.g., Vicki Norberg-Bohm \& Mark Rossi, The Power of Incrementalism: Environmental Regulation and Technological Change in Pulp and Paper Bleaching in the US, 10 TeCH. Analysis \& Strategic Mgmt. 225, 227 (1998) (noting that "innovation may begin prior to actual promulgation of environmental standards"); Nicholas A. Ashford \& George R. Heaton, Regulation and Technological Innovation in the Chemical Industry, 46 LAw \& CONTEMP. PROBS. 109, 120 (1983) (noting that the anticipation of the new regulations often prompts firms to make technological changes and come into substantial compliance well before the regulations are fully promulgated).

125 See Forest L. Reinhardt, Down to Earth: Applying Business Prin. CIPLES TO ENVIRONMENTAL MANAGEMENT 140-55 (2000) (describing firms that installed equipment in advance of the imposition of regulatory requirements).

126 Harter, Assessing the Assessors, supra note 5, at 57 tbl.1. Harter also states that the average duration of all negotiated rulemaking - by EPA as well as other agencies-should be lowered. He achieves this claimed reduction by truncating the duration of the Coast Guard Vessel Response Plan rulemaking, see supra note 120, and by excluding from the set of negotiated rules OSHA's rulemaking on occupational exposure to benzene. He claims it is inappropriate to include the benzene negotiations because OSHA never sent a representative to participate in them. Harter, Asssessing the Assessors, supra note 5, at 22 n.88. While it is true that OSHA did not take an active role as a participant in this negotiated rulemaking, "[ $t]$ his kind of agency nonparticipation had been recognized as one of the two basic forms of negotiated rulemaking." Perritt, supra note 16, at 1660. See also Henry H. Perritt, Jr., Administrative Alternative 
one rule that Harter argues should be excluded-the farmworker protection rule-happened to be the negotiated rulemaking with the longest duration. In addition, the two other rules-the equipment leaks and reformulated gasoline rules-were among those negotiated rules with the longest durations. Harter also questions the dates I use to calculate the duration of a fourth rule-the drinking water collection rule-although he does not change the dates I use in making his alternative calculation. ${ }^{127}$ In all, Harter disputes my time computations for the four EPA negotiated rules that had the longest rulemaking duration.

Due to the nature of an average (or mean) as a statistical measure, the average duration of negotiated rulemaking would indeed drop substantially if one were to remove the longest negotiated rulemaking from the group and also considerably shorten the duration of other rulemakings that took a longer time. This is explainable as a property of the statistic, since averages tend to be sensitive to outlying cases. Indeed, when analyzing a distribution of data with outliers in only a positive direction-such as with income or time, which can never be less than zero-the average will tend to be pulled upwards.128 In such cases, the median will generally be a more suitable indicator of the typical case, as it is less sensitive to extreme outliers. ${ }^{129}$ It is especially appropriate for a researcher to report the median in these cases, something that I did and Kerwin and Furlong did, but Harter did not.

As Table 1 shows, Kerwin and Furlong report an average rulemaking duration (1108 days) that was higher than the median duration (872 days). My analysis results in a similar distribution: a higher average duration for EPA's negotiated rulemakings

Dispute Resolution: The Development of Negotiated Rulemaking and Other Processes, 14 PEPP. L. Rev. 863, 881 (1987) (noting that Harter recognizes that negotiated rulemaking can occur without the participation of the agency). Perritt included the benzene negotiations in his evaluations of negotiated rulemaking. See id. at 874 . ACUS also included this rule in all its lists of federal agency negotiated rulemakings. ACUS, 1990 SOURCEBOOK, supra note 80, at 336; ACUS, 1995 SOURCEBOOK, supra note 4, at 382; ACUS, BUILDing CoNSENsus, supra note 80 , at 50 .

127 Harter, Assessing the Assessors, supra note 5, at 48.

128 See NeIl A. Weiss, InTROductory Statistics 129-30 (Sth ed. 1999).

129 See id. at 130 (showing that the median is a more resistant descriptive statistic, meaning that it is less sensitive to the influence of a few extreme data points). Accord Langbein \& Kerwin, supra note 89, at 610-11 (acknowledging that the median is the better measure of the typical number of comments filed on proposed rules when there are outliers). 
TABLE 1:

Duration OF EPA RulEMAKINGS (IN DAYS)

\begin{tabular}{lccc}
\hline & $\begin{array}{c}\text { Conventional Rules } \\
\text { (Kerwin \& Furlong) }\end{array}$ & $\begin{array}{c}\text { Negotiated Rules } \\
\text { (Coglianese) }\end{array}$ & $\begin{array}{c}\text { Negotiated Rules } \\
\text { (Harter) }\end{array}$ \\
\hline Average Duration & $1108^{\mathrm{a}}$ & $1013^{\mathrm{b}}$ & $751^{\mathrm{d}}$ \\
Median Duration & $872^{\mathrm{a}}$ & $777^{\mathrm{c}}$ & 743 \\
\hline
\end{tabular}

${ }^{a}$ Kerwin \& Furlong, supra note 40, at 134.

b Coglianese, Assessing Consensus, supra note 2, at 1283-84.

c Id. at 1284 n.123.

${ }^{d}$ Harter, Assessing the Assessors, supra note 5, at 57.

(1013 days) than a median duration for these same rules (872 days). This suggests that conventional rulemaking has had its outlying cases, just as has negotiated rulemaking. Harter's average for negotiated rulemaking is different, but only because he has truncated the data on negotiated rulemakings. Even though Harter's average duration is substantially lower than what I find, his median duration for negotiated rulemaking, not surprisingly, differs very little. ${ }^{130}$ When the data are properly analyzed, the median-as well as the average-duration of EPA's negotiated rulemakings is only ninety-five days shorter than the respective data from Kerwin and Furlong's comparison group. It should be remembered, of course, that by using the notice of intent to negotiate as the starting point for each rule, rather than EPA's internal records (the Kerwin and Furlong approach), 131 my study understates the duration of negotiated rulemaking by about 131 days compared with the approach used by Kerwin and Furlong. ${ }^{132}$

130 The median duration I reported for the twelve EPA negotiated rules was 777 days, while the median duration calculated using the numbers claimed by Harter is 743 days. Coglianese, Assessing Consensus, supra note 2, at 1284 n.123; Harter, Assessing the Assessors, supra note 5, at 57 tbl.1. This would mean that by Harter's computations negotiated rulemaking yields at best only about four months savings in median duration.

131 Kerwin and Furlong relied on EPA's "elaborate internal management mechanism," which, according to Kerwin and Furlong, has "reliable historical files on each rulemaking." Kerwin \& Furlong, supra note 40, at 119-20.

132 Coglianese, Assessing Consensus, supra note 2, at 1283. Furthermore, the findings from an independent study of rulemaking duration, conducted by political scientists Steven Balla and John Wright, confirm the basic conclusion that negotiated rulemaking does not shorten the regulatory process. After comparing the duration of rulemakings completed using different forms of public participation, Balla and Wright conclude:

Our research demonstrates ... that rules to which regulatory negotiation was applied took longer to issue than those developed through conventional proceedings, despite the fact agencies were more likely to conduct 


\section{Negotiated Rulemaking Demands More Time and Effort by Participants}

No matter what one concludes about the impact of negotiated rulemaking on the duration of the regulatory process, negotiated rulemaking still demands more time and effort on the part of the participants than does conventional rulemaking. ${ }^{133}$ Even if the overall duration of negotiated rulemakings could be shown to be shorter, ${ }^{134}$ the intensity of negotiated rulemakings still translates into additional time. As Harter himself acknowledges, "[r]eg negs are intense activities: participating in one can be expensive and time consuming." 135 The Langbein and Kerwin study, which Harter considers "rigorous" and "careful,"136 shows that participants in negotiated rulemakings report spending nearly twice as much overall in organizational resources as did their counterparts in conventional rulemakings. ${ }^{137}$ Strikingly, participants in negotiated rulemakings are three times more likely to complain that the process takes too much time and effort. ${ }^{138}$ Whatever one makes of the impact of negotiation on the duration of rulemakings, there is no disputing that negotiated rulemaking is much more burdensome, in terms of the overall time and expense, than conventional rulemaking. ${ }^{139}$

regulatory negotiations in situations that were amenable to relatively rapid resolution. In general, we find no evidence that consensual rulemaking reduces the time it takes to develop rules.

Balla \& Wright, supra note 107, at 26-27.

133 As Laura Langbein and Jody Freeman put it, "[t]his is one claim about reg neg that has no counterclaim." Jody Freeman \& Laura I. Langbein, Regulatory Negotiation and the Legitinacy Benefit, 9 N.Y.U. ENVTL. L.J. 60, 109 (2000). See also Mark Seidenfeld, Empowering Stakeholders: Limits on Collaboration as the Basis for Flexible Regulation, 41 WM. \& MARY L. REV. 411, 457 (2000) (observing that "all commentators agree that negotiated rulemaking is an intensive process requiring a concentrated devotion of resources by the agency and private negotiation participants").

134 As discussed in Part II.B, the evidence does not support such a conclusion.

135 Harter, Fear of Commitment, supra note 5, at 1420. See also id. at 1421 (admitting that negotiated rulemaking "is unquestionably an intense process").

136 Harter, Assessing the Assessors, supra note 5, at 55-56.

137 Langbein \& Kerwin, supra note 89, at 620.

138 Id.

139 See, e.g., Freeman \& Langbein, supra note 133, at 97 n.176 (acknowledging the "resource-intensive nature of reg neg"); CorNelius M. KERIVIs; Rulemaking: How Government Agencies Write Laiv and Make Policy 190 (1st ed. 1994) (observing that negotiated rulemaking demands an "exraordinary commitment of time" from individuals and that "negotiation sessions themselves are demanding activities that can wreak havoc with normal 
III

Negotiated Rulemaking and the Avoidance OF Litigation

Over the years, advocates of negotiated rulemaking consistently claimed that the procedure would eliminate subsequent litigation filed challenging administrative rules. ${ }^{140}$ Yet until I undertook my research, no one had sought to assess these claims by collecting comprehensive data on court filings for negotiated and conventional rules. Having collected this data for the EPA, I find that six out of the twelve completed EPA negotiated rules in my study have resulted in legal challenges, a litigation rate higher than that for all significant rules under EPA's major statutes and almost twice as high as that for EPA rules generally. ${ }^{141}$ Harter does not dispute that these challenges to negotiated rules were filed. ${ }^{142}$ Rather, he claims that negotiated rulemaking was never really meant to reduce litigation. ${ }^{143} \mathrm{He}$ also claims that I fail to account for differences in litigation and that when these differences are considered, negotiated rulemaking results in less protracted litigation. ${ }^{144}$ In this Part, I demonstrate that Harter is wrong on both counts: negotiated rulemaking has long aimed to reduce legal challenges to agency rules and it has failed to reduce both the number and intensity of these challenges.

work responsibilities"); Ellen Siegler, Regulatory Negotiations: A Practical Perspective, 22 Envtl. L. Rep. (Envtl. L. Inst.) 10,647, 10,651 (Oct. 1992) ("A major disadvantage of the reg-neg process is that it can be extremely resource-intensive and stressful."); ACUS, BuILDING CoNSENSUs, supra note 80, at 28 (reporting that the Department of Agriculture has found negotiated rulemaking to be "expensive"); OFFICE OF THE VICE PRESIDENT, supra note 42, at 31-32 ("The most significant deterrent to using negotiated rulemaking is its up-front cost. ... [T] he concentrated investment of effort and expense in the short term may be a serious obstacle."); Program Evaluation Division, supra note 78, at 23, 30 (noting that "EPA managers who have been the Agency's negotiators have devoted far more time to the negotiations in which they were involved than they ordinarily would spend on a single rulemaking effort").

140 See supra note 21 and accompanying text.

141 Coglianese, Assessing Consensus, supra note 2, at 1298-1301.

142 Harter even quotes a passage from Langbein and Kerwin in which they state that "negotiated rules appear no more (or less) subject to litigation than conventional rules." Harter, Assessing the Assessors, supra note 5, at 55 (quoting Langbein \& Kerwin, supra note 89, at 625). Langbein and Kerwin acknowledge that there is "little difference" in the litigation rates for negotiated rules and conventional rules. Langbein \& Kerwin, supra note 89, at 614-15.

143 See infra note 145 and accompanying text.

144 See infra notes 180-192. 


\section{A. Avoiding Litigation Has Long Been a Goal of Negotiated Rulemaking}

Harter suggests that it really does not matter that negotiated rulemaking has failed to prevent litigation. According to Harter, negotiated rulemaking was not originally intended to reduce litigation. For example, he asserts that "those who were present at the creation of reg-neg sought neither expedition nor a shield against litigation."145 Yet negotiation has long been offered, even in the early years, as an alternative that would reduce the perceived adversarial relationship between business and government. ${ }^{146}$ Former Secretary of Labor John Dunlop initiated interest in negotiated rulemaking in the 1970 s by calling attention to several problems with government regulation, one of which was "the legal game-playing between the regulatees and the regulators." 147 According to Dunlop, typically the "regulatory agency promulgates a regulation; the regulatees challenge it in court; if they lose, their lawyers may seek to find another ground for administrative or judicial challenge."148 $\mathrm{He}$ urged regulators to involve affected parties in the development of new rules so as to reduce the contentiousness, delays, and lawsuits that he perceived to be afflicting the regulatory process. ${ }^{149}$

Philip Harter himself, in his original article on negotiated rulemaking, advocated negotiated rulemaking as a cure for a "bitterly adversarial"150 regulatory process:

Negotiations may reduce judicial challenges to a rule because those parties most directly affected, who are also the most likely to bring suits, actually would participate in its development. Indeed, because the rule would reflect the agreement of the parties, even the most vocal constituencies should support

145 Harter, Assessing the Assessors, supra note 5, at 54.

146 See, e.g., Robert B. Reich, Regulation by Confrontation or Negotiation?, HARV. Bus. REv., May-June 1981, at 86, 91-92 (noting a substantial increase in the number of regulatory lawyers in Washington, D.C., and advocating regulatory negotiation as a solution to the "fruitless confrontation" and "protracted regulatory battles" perpetuated by lawyers); Peter H. Schuck, Litigation, Bargaining, and Regulation, Regulation, July-August 1979, at 26 (urging negotiation to avoid the "chronic fractiousness" of policymaking in the United States). See also Harter, Cure for Malaise, supra note 1, at $18 \mathrm{n} .96$ (citing early work complaining of adversarial relationships between business and government).

147 John T. Dunlop, The Limits of Legal Compulsion, 27 LAB. LJ. 67, 71 (1976).

148 Id.

$149 \mathrm{Id}$. at 72.

150 Harter, Cure for Malaise, supra note 1, at 18. 
the rule. This abstract prediction finds support in experience in analogous contexts. For example, there has been virtually no judicial review of OSHA's recent safety standards that were based on a consensus among the interested parties. Moreover, rules resulting from settlements have not been challenged. ${ }^{151}$

Moreover, according to Judge Loren Smith, chairman of ACUS at the time the Conference acted on Harter's report, "when we passed the first recommendation [encouraging agencies to use negotiated rulemaking]. .., the Reagan Administration's whole purpose on negotiated rulemaking was to keep things out of the courts." 152 In chronicling EPA's decision to launch its regulatory negotiation project in 1983, Daniel Fiorino and Chris Kirtz observed that the ACUS recommendation was one of the factors prompting EPA to pursue negotiated rulemaking. ${ }^{153}$ Furthermore, they point explicitly to the desire by EPA officials to reduce litigation:

[P]erhaps most importantly, people within the EPA were becoming more aware of the limits of conventional, adversarial rulemaking under the Administrative Procedure Act. The standard rulemaking process had become too susceptible to

151 Id. at 102 (footnotes omitted). See also supra note 13 and accompanying text. Harter did nevertheless originally predict that negotiated rules would be subjected to some litigation; however, over time he has become even more fervent in asserting that negotiated rules are resistant to legal challenge. See Coglianese, Assessing Consensus, supra note 2, at 1295 n.179 (noting the shift in Harter's claims about litigation).

152 Colloquium, The Fifth Annual Robert C. Byrd Conference on the Administrative Process: The First Year of Clinton/Gore: Reinventing Government or Refining Reagan/Bush Initiatives?, 8 ADMIN. L.J. AM. U. 23, 62 (1994) (statement by Judge Loren Smith).

153 See Daniel J. Fiorino \& Chris Kirtz, Breaking Down Walls: Negotiated Rulemaking at EPA, 4 TEMP. ENVTL. L. \& TECH. J. 29, 29 (1985). One of the leading figures in the development of the regulatory negotiation project at EPA, Joseph Cannon, apparently was motivated by his commitment to "the idea that many disputes were best resolved out of court." Susskind \& McMahon, supra note 101, at 142 n.53. EPA Administrator Lee Thomas similarly stressed EPA's desire to shorten rulemaking time and reduce litigation as among the chief reasons for the agency's regulatory negotiation initiative. Lee M. Thomas, The Successful Use of Regulatory Negotiation, supra note 77, at 3. Furthermore, the training material EPA provided to participants in its second negotiated rulemaking described EPA's Regulatory Negotiation Project as an opportunity to "test whether negotiation at an early stage of rulemaking can produce rules more quickly, less expensively, and with less likelihood of litigation." EPA, Training Session on Negotiating Techniques for the PestiCide EXemption Negotiating Committee 1 (Sept. 27, 1984), reprinted in ACUS, 1995 SOURCEBOOK, supra note 4, at 199, 202. 
delay and litigation. As many as 80 percent of EPA's final rules are challenged -often by both sides of an issue. A pilot program on regulatory negotiation offered an opportunity to test an alternative method for proposing Agency rules that would permit all participants a face-to-face role in decisionmaking. 154

As one can plainly see, the aim of avoiding litigation motivated both the original ACUS recommendation urging agencies to pursue negotiated rulemaking and EPA's decision to launch its regulatory negotiation project.

Admittedly, over the years advocates of negotiated rulemaking have claimed a number of additional benefits from negotiated rulemaking, ${ }^{155}$ but from the very beginning proponents have consistently claimed that it will reduce legal challenges to agency rules. ${ }^{156}$ Numerous practitioners, academics, legislators, and agency officials have advocated negotiated rulemaking as a way of reducing subsequent litigation, which many erroneously thought had reached the point where groups challenged four out of every five regulations EPA issued. ${ }^{157}$ The Negotiated Rulemaking Act included in its preamble the goal of reducing the likelihood of litigation. ${ }^{158}$ In addition, Republican and Democratic administrations endorsed the use of negotiated rulemaking, in no small part because of the belief that the procedure

154 Fiorino \& Kirtz, supra note 153, at 29.

155 For example, in a recent discussion of EPA's public participation efforts, Charles Fox of EPA opined that the rules his agency negotiated have been "more practical and cost efficient, contained more innovative solutions, were more technically and scientifically current, and had greater legitimacy." J. Charles Fox, $A$ Real Public Role, 15 EnvTL. F. 19, 24 (1998). He also asserted that negotiated rulemaking has saved the agency time and has prevented litigation. Id.

156 For a detailed account of the emphasis placed on litigation avoidance in the legislative history leading up to the Negotiated Rulemaking Act of 1990 and its permanent reauthorization in 1996, see Coglianese, Assessing Consensus, supra note 2 , at $1262-71$.

157 For an extensive bibliography of this literature, see id. at 1343 app. D. The refrain of Lawrence Susskind reflects the tenor of the literature: "All too often government regulations end up as the subject of lawsuits. We could reduce this wrangling if the opposing sides drafted the regulations together." Susskind \& Van Dam, supra note 1 , at 38.

158 The Negotiated Rulemaking Act of 1990, supra note 16, Pub. L. No. 101-648, § 2(5), 104 Stat. 4969 ("Negotiated rulemaking can increase the acceptability and improve the substance of rules, making it less likely that the affected parties will resist enforcement or challenge such rules in court."). 
would minimize litigation. ${ }^{159}$ Advocates have consistently emphasized negotiated rulemaking's potential for reducing litigation, and even the earliest "pioneers" of the process have boasted (inaccurately) that the negotiation process has "almost eliminated" subsequent litigation 160 and that "no rule crafted in this manner has been subjected to court action."161

\section{B. Negotiated Rulemaking Has Failed to Reduce Litigation}

Even though Harter erroneously suggests that it does not really matter that negotiated rulemaking has generated a considerable number of legal challenges, ${ }^{162}$ he nevertheless makes several forcefully worded, but mistaken, criticisms of my analysis of negotiated rulemaking and litigation. ${ }^{163}$ For example, he first accuses me of "significantly misleading" the reader by including a discussion of the Grand Canyon visibility negotiation in Assessing Consensus, because it was not technically a negotiated rulemaking. ${ }^{164}$ At the same time, however, he readily acknowledges that my article "points out that this rule was not developed

159 The Clinton Administration's National Performance Review urged the use of negotiated rulemaking as an effective alternative to a rulemaking process that, in language Harter quotes, "encourages adversarial, uncooperative behavior on the part of private industry or others who might be affected by an agency's decisions, which frequently leads to protracted litigation." OFFICE OF THE Vice President, supra note 42, at 29, quoted in Harter, Assessing the Assessors, supra note 5 , at 37 . In addition to signing the reauthorization of the Negotiated Rulemaking Act, President Clinton also issued several directives to agencies to use negotiated rulemaking. See Exec. Order No. 12,866, 3 C.F.R. $\S \S 638,642-43$ (1994), reprinted in 5 U.S.C. $\S \S 601,644-645$ (1994); Negotiated Rulemaking, Memorandum for Executive Departments and Selected Agencies [and the] Administrator of the Office of Information and Regulatory Affairs, 58 Fed. Reg. 52,391 (Oct. 7, 1993); President's Memorandum on Regulatory Reform, 1995 Pub. PAPERs 304, 305 (Mar. 4, 1995); President William Clinton and Vice President Albert Gore, Reinventing Environmental Regulation 5, 9 (1995) (available from the ELR Doc. Serv., ELR Order No. AD-979). President Bush signed the original Negotiated Rulemaking Act, stating that negotiated rulemaking would provide "a means of avoiding costly and time-consuming litigation." President's Statement on Signing the Negotiated Rulemaking Act of 1990, 1990 Pub. PAPERS 1716 (Nov. 29, 1990).

160 John T. Dunlop \& Arnold M. Zack, Mediation and Arbitration OF EMPLOYMENT Disputes 48 (1997).

161 Philip J. Harter \& Daniel Finkelstein, The Coke Ovens' Regulatory Negotiation: From Choking Controversy to Consensus Relief, 2 J. EnvTL. PERMiT: TING 343, 345 (1993).

162 See supra Part III.A.

163 Harter, Assessing the Assessors, supra note 5, at 52 (asserting that "Coglianese paints a substantially misleading picture").

$164 \mathrm{Id}$. at 50. 
under the Negotiated Rulemaking Act."165 In addition to stating that the rule was not technically a negotiated rulemaking under the Act, I also expressly exclude the Grand Canyon rule when calculating and discussing the overall litigation rate for EPA's negotiated rules. ${ }^{166}$ Nevertheless, mentioning the litigation over the Grand Canyon rule as I do is far from misleading-it is relevant and highly probative support for the proposition that "rules promulgated following a regulatory negotiation are far from immune from legal challenge."167 The Grand Canyon rule was probably the most well publicized of any EPA regulatory negotiation, having concluded with a dramatic presidential ceremony near the edge of the Grand Canyon and prompting a front-page New York Times article hailing the negotiation process as a model alternative to the "lawsuit system."16s Moreover, at the time of my original research, the Grand Canyon rule had been heralded as a negotiated rulemaking success story by one of the sponsors of the Senate bill permanently reauthorizing the Negotiated Rulemaking Act. ${ }^{169}$ At that time, however, the rulemaking had been discussed in the legal literature only "as a prototype 'win-win' solution of an environmental problem and a model for other regulatory negotiations."170 Thus, including mention of the Grand Canyon litigation actually helps to correct the misleading impression that regulatory negotiation eliminates subsequent legal challenges to agency rules.

165 Id. Indeed, I note at the outset of my discussion of this prominent regulatory negotiation that it was "not conducted under the auspices of the Negotiated Rulemaking Act." Coglianese, Assessing Consensus, supra note 2, at 1288. In a footnote, I elaborate that EPA did not invoke the Negotiated Rulemaking Act because the negotiations occurred after, instead of before, the publication of the proposed rule. Id. at 1288 n.138.

166 Id. at $1301-1302$.

167 Id. at 1287.

168 See Matthew L. Wald, U.S. Agencies Use Negotiations to Preempt Law' Suits Over Rules, N.Y. Times, Sept. 23, 1991, at A1, quoted in Coglianese, Assessing Consensus, supra note 2, at 1289 (describing the Grand Canyon visibility rule).

169 Gov't Press Release, Clinton Signs Levin's Bill Encouraging Government Innovation (Oct. 21, 1996), available at 1996 WL 11125786 (press release issued by Senator Carl Levin).

170 D. Michael Rappoport \& John F. Cooney, Visibility at the Grand Canyon: Regulatory Negotiations Under the Clean Air Act, 24 ARIz. Sr. LJ. 627, 627 (1992). 
Harter also charges that I fail to look into the details surrounding the challenged negotiated rules and their litigation. ${ }^{171}$ This claim is yet another example of Harter's advocacy. Even a cursory reading of Assessing Consensus reveals that I devote considerable attention to the details surrounding all six EPA negotiated rulemakings that were subject to legal action, stating exactly who filed each petition for review, why, and to what effect. ${ }^{172}$ Harter's claim that I fail to look at what happened in these cases is all the more interesting since he himself provides only two paragraphs in his article to the litigated rules, compared with the more than eight pages contained in my original article. ${ }^{173} \mathrm{He}$ devotes a mere eleven words to the litigation challenging the disinfectant byproducts rule compared with the page and a half I devote to that rule and its subsequent legal challenge. ${ }^{174}$

Perhaps because his own discussion of the challenged rules is so brief, Harter creates some confusion about the litigation filed against the reformulated gasoline rule and the equipment leaks rule. ${ }^{175}$ Without denying that court petitions were filed

171 Harter, Assessing the Assessors, supra note 5, at 50 (asserting that "Coglianese fails to look at either what happened in the negotiated rulemaking itsclf or the nature of the challenges").

172 Coglianese, Assessing Consensus, supra note 2 at 1290-92, 1302-1308.

173 Compare Harter, Assessing the Assessors, supra note 5, at 50-52, with Coglianese, Assessing Consensus, supra note 2, at 1290-92, 1302-1308.

174 Compare Harter, Assessing the Assessors, supra note 5, at 51, with Coglianese, Assessing Consensus, supra note 2, at 1306-1307. I recognize that for some readers it may seem unusual to compare the number of words or pages contained in scholarly articles, but the stark contrast in the volume of text alone provides a clear indication of the degree to which I provide background information about EPA's challenged negotiated rulemakings. This point bears emphasizing since Freeman and Langbein have echoed Harter's charges, criticizing my study for failing to provide "contextual details" while characterizing Harter's brief treatment as "a detailed analysis of the circumstances surrounding a variety of challenges to negotiated rules." Freeman \& Langbein, supra note 133, at $145 \mathrm{n} .357$ and accompanying text. The reality is that Harter gives scant attention to these challenges, and offers no new information, while I provide more detailed information about all the challenges to EPA's negotiated rules than found anywhere else in the literature.

175 In this brief discussion Harter also manages to make another mistake. In a footnote to his discussion of EPA's negotiated rulemaking on the underground injection of hazardous wastes (initiated under RCRA), he confuses this negotiated rulemaking with one that EPA proposed, but ultimately abandoned, on underground injection control for Class II wells in connection with oil and gas drilling (initiated under the Safe Drinking Water Act). In his discussion of the RCRA rule, Harter suggests that I mistakenly treat the SDWA rule as abandoned and claims that the latter was also negotiated. Harter, Assessing the Assessors, supra note 5 , at $51 \mathrm{n} .97$ (asserting that the Class II underground 
challenging these rules, he nevertheless mistakenly implies that the challenges I attribute to these two rules were actually filed against related, but distinct EPA rules that were not negotiated. ${ }^{176}$ Yet, even though petitions were filed against related

injection control negotiated rulemaking "continued to full term but no agreement was reached"). Yet the record is clear that EPA really did abandon the SDWA negotiated rulemaking on Class II wells. EPA's own internal lists of its negotiated rulemaking do not even mention the Class II underground injection control matter. See, e.g., EPA, Negotlated Rulemaking at the ENviroN. MENTAL PRotection Agency 4 (Mar. 1992) (on file with the author); EPA, Negotiated Rulemiaking at the Environmental Protection Agency 5 (Oct. 1992) (on file with the author); EPA, Negotiated Ruleniaking at the Environmental Protection Agency 6 (Nov. 18, 1994) (on file with the author). The ACUS list of EPA's negotiated rulemakings does mention the issue, but notes that even though "EPA considered establishing a committee to negotiate rules under the Safe Drinking Water Act, pertaining to underground injection control associated with oil and gas production[, t]he agency subsequently decided not to go forward with negotiations, but did form a committee to give advice on options." ACUS, 1995 SOURCEBOOK, supra note 4, at 392. EPA did initially indicate its inclination to move forward to propose amendments to its underground injection control rules for Class II wells using a negotiated rulemaking process. See Underground Injection Control, Class II, Wells; Intent to Form an Advisory Committee to Negotiate Amendments to Regulations, 56 Fed. Reg. 4957 (Feb. 7, 1991). However, only a few months later EPA determined that it was not sure that amendments to these rules were yet warranted and decided that it would not proceed with a negotiated rulemaking. See Underground Injection Control, Class II, Wells; Intent to Form an Advisory Committee to Resolve Issues Related to the Class II Program, 56 Fed. Reg. 14,521, 14,521 (Apr. 10,1991). Instead it established an advisory committee to consider the "potential" for creating new amendments to the Class II well program. See Establishment and Open Meeting of the EPA Advisory Committee for Class II Underground Injection Control Program, 56 Fed. Reg. 26,672, 26,673 (June 10, 1991). The Federal Register notice of the first meeting of this advisory committee nowhere mentions that the committee was proceeding with a negotiated rulemaking. See 56 Fed. Reg. at 26,673. My interview notes, taken in the course of conducting my research for Assessing Consensus, indicate that the key EPA staff member involved in this process reported that about seven advisory committee meetings were held from the middle of 1991 to early 1992, but that by the mid-1990s EPA made a decision to abandon any further efforts to consider new Class II well regulations for the oil and gas industry.

176 On the reformulated gasoline rule, Harter states that "[t]here were indeed a number of challenges to the application of the rule, but amazingly few challenges to the rule itself." Harter, Assessing the Assessors, supra note 5, at 50 (footnotes omitted) (citing the challenge to the renewable oxygenates companion rule in connection with the "application of the rule") (emphasis added). On the equipment leaks rule, Harter admits that it was challenged, but suggests that the challenge may have been to other portions of the Hazardous Organies NESHAPS (HON) rule, to which the equipment leaks rule was attached. Harter, Assessing the Assessors, supra note 5, at 51 (asserting that "a challenge to other parts of the HON should not be ascribed to the Equipment Leaks part of the rule"). Following Harter's example, Freeman and Langbein also claim that 
rules, court records in both cases show that petitioners also challenged the very rules which were developed through negotiated rulemaking. 177 Although those who advocate negotiated rulemaking have created some ambiguity on this point, the fact is that the reformulated gasoline rule itself was challenged ${ }^{178}$ as was the equipment leaks portion of the HON rule which was developed through negotiated rulemaking. ${ }^{179}$

Finally, Harter claims that I fail to distinguish "substantive challenges" from other kind of challenges, and that negotiated rules have been "remarkably resistant" to such substantive challenges. ${ }^{180}$ Since he never defines what he means by a "substantive challenge," it not possible to test or respond to his claim fully. Once again, Harter's approach may well be understandable as a form of advocacy, but it is unacceptable as a basis for empirical analysis of negotiated rulemaking. ${ }^{181}$ If, in claiming that I fail to distinguish between "substantive" and other types of challenges, Harter means to imply that I fail to report that most of the challenges to negotiated rules were settled out of court, then again a casual reading of Assessing Consensus is enough to

the legal challenges in these rulemakings only addressed aspects that were not negotiated. Freeman \& Langbein, supra note 133, at $145-46$ n.212, 172 n.359 (arguing that the litigation filed against the equipment leaks and reformulated gasoline rule only targeted aspects that were not negotiated).

177 See Coglianese, Assessing Consensus, supra note 2, at 1307-1308 n.246.

178 See, e.g., Am. Petroleum Inst. v. EPA, No. 94-1138 (D.C. Cir. filed Feb. 24, 1994); Texaco, Inc. v. EPA, No. 94-1143 (D.C. Cir. filed Feb. 25, 1994). See Fina Oil \& Chem. Co. v. EPA, No. 94-1142 (D.C. Cir. Feb. 25, 1994); Amerada Hess Corp. v. EPA, No. 94-1319 (D.C. Cir. Filed Apr. 15, 1994); National Tank Truck Carriers, Inc. v. EPA, No. 94-1323 (D.C. Cir. Filed Apr. 18, 1994). See also Coglianese, Assessing Consensus, supra note 2, at 1290-92.

179 See Attachment A to Settlement Agreement at 102-22, Chem. Mfrs. Ass'n v. EPA, No. 94-1463 (D.C. Cir. Aug. 30, 1996), quoted in Coglianese, Assessing Consensus, supra note 2, at 1307 n.246. See also Coglianese, Assessing Consensus, supra note 2, at 1304-1305.

180 Harter claims that "the rules that have emerged from negotiated rulemaking have been remarkably resistant to substantive challenges" and that "reg* negs have been phenomenally successful in warding off substantive review." Harter, Assessing the Assessors, supra note 5, at 51-52. Without any definition of what counts as a "substantive" lawsuit, Harter's claims are not falsifiable, a central requirement for social science research. KING ET AL., supra note 33, at 100-105 (explaining that social science claims must be capable of being shown to be wrong). As discussed in the text infra, all observable indicators reveal that litigation filed against EPA's negotiated rules does not differ in any appreciable way from that filed generally against EPA rules.

181 KING ET AL., supra note 33, at 20 (noting that empirical claims should "be as concrete as possible. Vaguely stated theories and hypotheses serve no purpose but to obfuscate."). 
show that he is mistaken. ${ }^{182}$ Harter notes that several of the challenges to negotiated rules were withdrawn after settlement talks in several cases, but in each case I already note this in Assessing Consensus. ${ }^{183}$ In fact, I specifically report that "only two of the six challenged rules reached an appellate panel for a decision," the rest having been voluntarily dismissed by the parties. ${ }^{184}$

I also report-and this is most crucial-that most petitions for review of EPA rules are voluntarily dismissed by the parties. ${ }^{185}$ Indeed, settlement is more common in litigation challenging EPA rules than with other litigation. As I report in an earlier study cited in Assessing Consensus, "[t]he settlement rate for EPA rule challenges in the DC Circuit ... is nearly twice that for all appeals ... and substantially more than the rate for all administrative appeals."186 Organizations filing suits challenging EPA rules often do so to preserve the opportunity to work out additional changes in the rule, aware that the underlying environmental statutes authorizing judicial review require such suits to be filed, if at all, within a few months of the promulgation of the final rule. ${ }^{187}$ For many organizations filing petitions for review of

182 Coglianese, Assessing Consensus, supra note 2, at 1290-92, 1302-1307 (describing legal challenges to negotiated rules and their disposition). Furthermore, a reading of an earlier study of mine, cited in Assessing Consensus, is enough to show that Harter is mistaken in suggesting that I more generally failed to appreciate different kinds of litigation. Cary Coglianese, Litigating Within Relationships: Disputes and Disturbance in the Regulatory Process, 30 LAw \& Soc'y REv. 735, 736-37, 753-62 (1996) [hereinafter Coglianese, Litigating Within Relationships] (emphasizing the heterogeneity of litigation).

183 For example, Harter notes that, in the equipment leaks rule, the chemical industry simply "filed a defensive challenge while it worked out some minor details of the regulation. Those negotiations were successful and the challenge was withdrawn." Harter, Assessing the Assessors, supra note 5, at 51. I already described these settlement negotiations and reported that this challenge was ultimately withdrawn. Coglianese, Assessing Consensus, supra note 2, at 1304 1305,1307 n.246.

$184 \mathrm{Id}$. at 1308.

185 Id.

186 Coglianese, Litigating Within Relationships, supra note 182, at 756 (parentheticals omitted), cited in Coglianese, Asssessing Consensus, supra note 2, at 1308 n.247.

187 See Clean Air Act, 42 U.S.C. \$ 7607(b) (1994) (60-day period); Clean Water Act, 33 U.S.C. § 1369(b)(1) (1994) (120-day period); Resource Conservation and Recovery Act, 42 U.S.C. § 6976(a)(1) (1994) (90-day period); Safe Drinking Water Act, 42 U.S.C. § 300j-7 (1994) (45-day period); Surface Mining Control and Reclamation Act, 30 U.S.C. § 1276(a)(1) (1994) (60-day period); Toxic Substances Control Act, 15 U.S.C. § 2618(a)(1) (1994) (60-day period). 
EPA rules, the petition simply signals the beginning of a new round of working out the details of the rule with the agency. Industry and environmental groups frequently treat litigation as a continuation of the rulemaking process, albeit with a smaller number of participants. ${ }^{188}$

Thus when Harter suggests that negotiated rulemaking has spared EPA highly protracted litigation because many of the challenges to these rules were eventually withdrawn, he is actually describing the normal pattern of challenges to EPA. As I report in Assessing Consensus:

For all challenges to EPA rules filed in the D.C. Circuit between $1979-1990$, only $29 \%$ were resolved through adjudication before an appellate panel. Negotiation and settlement discussions typically follow the filing of challenges to any EPA rule .... In the aggregate, negotiated rulemaking has not generated any substantial difference in the way that legal challenges get resolved. ${ }^{189}$

Indeed, the litigation against negotiated rules turns out to be virtually the same as litigation against conventional rules along every dimension, except that negotiated rules are challenged at a higher rate. 190 A single rule can, of course, be challenged by more than one organization. The data reveal not only that negotiated rules are challenged at a higher rate, but also that each challenge involves on average a somewhat larger number of petitioners. As Table 2 shows, the average number of petitions filed against negotiated rules is actually somewhat higher than the average number of petitions in challenges to conventional rules overall (3.7 petitions per challenged negotiated rule versus 3.0 for challenged conventional rules). ${ }^{191}$ The rate at which these challenges eventually reach a court for decision is about the same as for challenges to conventional rules, and courts have been equally deferential in adjudicated challenges to negotiated rules as they are more generally in all challenges to EPA rules. ${ }^{192}$ The typical challenge filed against an EPA negotiated rule does not differ in any discernible way from the typical challenge filed against a conventional rule.

\footnotetext{
188 Coglianese, Litigating Within Relationships, supra note 182, at 757-58.

189 Coglianese, Assessing Consensus, supra note 2, at 1308.

190 See infra tbl.2.

191 Coglianese, Assessing Consensus, supra note 2, at 1310 n.252.

192 Id.
} 


\section{TABLE 2:}

Litigation Challenging EPA Rulemakings

\begin{tabular}{lcc}
\hline & $\begin{array}{c}\text { Rulemaking } \\
\text { Overall }\end{array}$ & $\begin{array}{c}\text { Negotiated } \\
\text { Rulemaking }\end{array}$ \\
\hline Percentage of Rules Challenged & $35 \%^{\mathrm{a}}$ & $50 \%^{\mathrm{b}}$ \\
$\begin{array}{l}\text { Number of Petitions Filed Per } \\
\text { Challenge }\end{array}$ & $3.0^{\mathrm{c}}$ & $3.7^{\mathrm{s}}$ \\
$\begin{array}{l}\text { Percentage of Filed Petitions } \\
\text { Decided by Court }\end{array}$ & $29 \%^{\mathrm{e}}$ & $33 \%^{\mathrm{s}}$ \\
$\begin{array}{l}\text { Percentage of Adjudicated Cases } \\
\text { Decided for EPA }\end{array}$ & $51 \%^{\mathrm{s}}$ & $50 \%^{\mathrm{B}}$ \\
\hline
\end{tabular}

${ }^{a}$ Coglianese, Assessing Consensus, supra note 2, at 1300.

${ }^{\mathrm{b}} \mathrm{Id}$.

c Id. at $1310 \mathrm{n} .252$

dId.

' Id. at 1308 n.247.

if $I$ at 1308.

${ }^{B}$ Id. at $1308-1309$ n.249.

${ }^{\mathrm{b}} \mathrm{Id}$.

\section{Negotiated Rulemaking Engenders Additional Conflict}

Not only does negotiated rulemaking fail to eliminate litigation or reduce its intensity, it also results in more legal challenges than would otherwise be expected. These legal challenges have been filed both by participants in negotiated rulemakings and by organizations who were not part of the negotiation process. ${ }^{193}$ As I explain in Assessing Consensus, the failure of negotiated rulemaking to live up to expectations is in part explained by the fact that conventional rulemaking at EPA has been much more resistant to litigation than anyone previously believed.194 It is also the case that negotiation efforts do not resolve all conflicts, and, in some ways, they can even engender new conflicts. As we have seen, consensus is not always attainable, and even when it is, it may only temporarily hide underlying conflicts. ${ }^{195}$ Negotiated rulemaking also creates new sources of conflict that do not exist with other methods of policy making. ${ }^{196}$ Conflicts can arise over the selection of participants in the negotiations, the meaning of agreements that are reached, and whether the final rule is con-

193 See id. at 1302.

194 Id. at 1330-34.

195 See supra Part II.A. See also Coglianese, Assessing Consensus, supra note 2, at 1290-94 (describing conflicts underlying challenges to the reformulated gasoline rule).

196 See Coglianese, Is Consensus Appropriate?, supra note 2, at 112-13. 
sistent with those agreements. ${ }^{197}$ Disagreements can even arise about the implications of silence in the agreement over particular terms or issues. ${ }^{198}$ None of these additional kinds of conflict arise in the absence of negotiated rulemaking.

A recent negotiated rulemaking effort at the Department of Housing and Urban Development (HUD) illustrates one of these new sources of conflict. HUD had originally named four public housing organizations to serve on negotiated rulemaking committees for regulations addressing subsidies and capital funds. ${ }^{199}$ After the housing organizations subsequently filed a petition against the agency over a separate matter, HUD officials unilaterally declared that the organizations could no longer bargain with the agency in good faith and removed them from the negotiated rulemaking committees. ${ }^{200}$ The housing groups filed for a court order reversing their removal from the committee, arguing that HUD's action discriminated against them in the exercise of their fundamental right of petition. ${ }^{201}$ HUD eventually capitulated and reinstated the organizations as members of the negotiated rulemaking committees, but the experience demonstrates a profound new source of litigated conflict that, ironically, is found only in the very process that was intended to reduce litigation.

\section{IV}

Negotiated Rulemaking's Promise REMAINS UNFULFILLED

Harter concludes his critique by downplaying the importance of determining whether negotiated rulemaking reduces the incidence of litigation or shortens the duration of the process: $\mathrm{He}$ argues that the primary objective of negotiated rulemaking is to create better regulatory policy and that it has achieved that

197 For examples of the range of conflicts engendered by negotiated rulemaking agreements, see Coglianese, Assessing Consensus, supra note 2, at 1322-27. 198 Id.

199 Notice of Intent to Establish a Negotiated Rulemaking Committee, 64 Fed. Reg. 5570, 5571 (Feb. 3, 1999); Establishment of Negotiated Rulemaking Committee, 64 Fed. Reg. 12,920, 12,921 (Mar. 16, 1999).

200 HUD Tells PHA Organizations They Shouldn't Participate on Negotiated Rulemaking Committees, [Current Developments] Hous. \& Dev. Rep. (West), 757-58 (April 5, 1999).

201 Motion for Temporary Restraining Order, Council of Large Pub. Hous. Auths., Inc. v. U.S. Dep't of Hous. \& Urban Dev. (D.D.C. Mar. 25, 1999) (No. 1:99CV00634). 
goal.202 According to Harter, negotiated rulemaking has proved to be "an enormously powerful tool" for developing better rules. ${ }^{203} \mathrm{He}$ claims that negotiated rulemaking "has enabled the parties to address the best, most effective, or most efficient way of solving a regulatory controversy."204 These benefits, he argues, "flow[] from the participation of those affected, who bring with them a practical insight and expertise that can result in rules that are better informed, more tailored to achieving the actual regulatory goal, and hence, more effective and more enforceable."205

Harter claims that the findings of the study by Laura Langbein and Neil Kerwin provide "particularly powerful" support for his claim that negotiated rulemaking improves the quality of regulatory decisions. ${ }^{206}$ That study reports that participants in negotiated rulemakings perceive the resulting final rules more favorably than do those who file comments in conventional rulemakings. ${ }^{207}$ Once again, however, Harter engages in faulty empirical analysis and uses it in an effort to bolster support for negotiated rulemaking. The Langbein and Kerwin study actually provides no basis for drawing inferences about the quality of negotiated rules. 208 Furthermore, Harter disregards the problems that negotiated rulemaking can create and overlooks alternative methods of public participation that can provide agencies with the same "practical insight and expertise,"209 and other alleged benefits of negotiated rulemaking, all without relying on consensus as the basis for public policy. In the absence of demonstrable improvements in regulatory decisions, negotiated rulemaking's failure to shorten the rulemaking process or reduce litigation will remain a relevant and important consideration in evaluating the role of formal negotiations in administrative law.

202 Harter, Assessing the Assessors, supra note 5, at 52. Freeman and Langbein echo Harter, arguing that "time and litigation rates tell only part of the story and although relevant, they remain secondary to improved rule quality and legitimacy." Freeman \& Langbein, supra note 133, at 128.

203 Harter, Assessing the Assessors, supra note 5, at 56.

204 Id. at 38.

205 Id. at 54. Although Harter's rhetoric may sound a bit exaggerated, he is not alone among advocates in sounding such an enthusiastic refrain. See, e.g., Fox, supra note 155.

206 Harter, Assessing the Assessors, supra note 5, at 56.

207 Langbein \& Kerwin, supra note 89, at 602-605.

208 See infra Part IV.A.

209 See supra note 205. 


\section{A. Langbein and Kerwin's Study Does Not Address the Quality of Rules}

Laura Langbein and Cornelius Kerwin interviewed 101 participants in eight EPA negotiated rulemakings and fifty-one randomly selected individuals who had submitted comments in six conventional rulemakings conducted by EPA. ${ }^{210}$ They asked both sets of respondents a series of questions about their experience with the rulemaking in which they were involved and about their perceptions of the process and resulting rule. ${ }^{211}$ Using an eleven-point scale (from -5 to +5 ), participants were asked to rate the final rules on a number of criteria, including the economic efficiency and cost-effectiveness of the final rule, the quality of the scientific evidence used to create the final rule, and the appropriateness of the final rule's use of technology. ${ }^{212}$ Langbein and Kerwin found that the differences between the responses of participants in negotiated and conventional rulemakings were in many cases statistically significant and resulted in more positive average ratings by the participants in negotiated rulemakings. ${ }^{213}$ Harter makes much of these differences, even to the point of including Langbein and Kerwin's data in a table in his article, and urges that they demonstrate that negotiated rulemaking does achieve better rules. ${ }^{214}$ The Langbein and Kerwin study, he argues, shows that " $\mathrm{t}]$ he benefits envisioned by the proponents of negotiated rulemaking have indeed been realized." 215

Yet the study conducted by Langbein and Kerwin does not demonstrate that such benefits have been realized. The data they report are at best evidence of the perceptions of participants, not evidence of the underlying qualities that would make for a better rule, such as efficiency or effectiveness. As Langbein and Freeman state in their recent discussion of the Langbein and Kerwin study, "[a]s to whether reg neg produces 'better rules' in some objective sense, we cannot say."216

Before explaining why this is so, two other limitations of the Langbein and Kerwin data should be noted. First, the types of respondents in the negotiated rulemaking sample differ consider-

210 Langbein \& Kerwin, supra note 89 , at 601 .

211 Id. at 600-602.

212 Id. at 603-604.

213 Id. at 604 exhib.1.

214 See Harter, Assessing the Assessors, supra note 5, at 55-56, 59 tbl.3.

215 Id. at 56.

216 Freeman \& Langbein, supra note 133, at 66. 
ably from the types of respondents in the conventional rulemaking sample. Langbein and Kerwin report that of all the types of participants in negotiated rulemakings, the representatives from EPA and state government gave negotiated rulemaking the highest overall ratings. ${ }^{217}$ This is important to recognize because approximately eleven percent of the negotiated rulemaking participants they interviewed were EPA officials and approximately twenty-five percent were representatives from state and local government. ${ }^{218}$ In contrast, the sample of individuals who filed comments in conventional rulemakings obviously included no one from EPA $^{219}$ and included only three representatives from state and local government.220 Thus, approximately thirtysix percent of the respondents from negotiated rulemakings were individuals who might be considered "enthusiasts," given their higher overall ratings, while only approximately six percent of the comparison group were. ${ }^{221}$ We should not be surprised, of course, if government regulators tend to rate government regulations, whether negotiated or otherwise, more favorably than those whom the regulations affect.222 In addition, we should also not be surprised if those who help to craft a negotiated rule report more favorable ratings than those who file comments on a proposed rule, since presumably people tend to file comments when they have complaints they wish to air. Notably, only

217 Cornelius M. Kerwin \& Laura I. Langbein, An Evaluation of Negotiated Rulemaking at the Environmental Protection Agency: Phase II, A Comparison of Conventional and Negotiated Rulemaking 45 tbl.46 (August 1997) [hereinafter Kerwin \& Langbein, Phase II] (unpublished report prepared for the Environmental Protection Agency, on file with N.Y.U. Environunental Law Journal); see also Freeman \& Langbein, supra note 133, at 61 n.5.

218 Kerwin \& Langbein, Phase II, supra note 217, at 45 tbl.1.

219 Langbein \& Kerwin, supra note 89, at 620. The fact that EPA officials would never be included in a sample derived from commenters is so obvious that it is remarkable to find Langbein and Freeman now claiming that "participants, including EPA, rate the outcomes of negotiated rules as better than the outcomes from conventional rulemaking." Freeman \& Langbein, supra note 133, at 66 (emphasis added). We cannot infer anything at all about how EPA officials compare negotiated and conventional rulemaking from a study that only asks their views of negotiated rulemaking. It may be relevant, however, to consider that EPA has not commenced a new negotiated rulemaking proceeding since 1993.

220 Kerwin \& Langbein, Phase II, supra note 217, at 45 tbl.1.

221 Id.

222 Cf. WeIss, supra note 33, at 147 (noting that "[h]owever objective they may be, staff members can be suspected of bias-often justly-in the direction of seeing improvement where none exists"). 
twenty-four percent of the negotiated rulemaking respondents came from business, compared with sixty-seven percent of the respondents in the conventional rulemaking sample. The differences in the average ratings reported by Langbein and Kerwin, and relied on by Harter, seem likely to reflect these differences in the makeup of the samples. ${ }^{223}$

Second, although Langbein and Kerwin claim their data reveal that participants in negotiated rulemakings have a "higher level of satisfaction with the final rule," 224 one of the negotiated rulemakings in their study-the hazardous waste manifest

223 Langbein and Kerwin purport to control for the affiliation of their respondents in their regression analysis. See Langebein \& Kerwin, supra note 89, at 623-24. However, their model fails to provide a sufficient basis for ruling out the effects of respondents' affiliation on the results that Harter cites. First, Langbein and Kerwin only report having attempted to control for the effects of affiliations on respondents' overall ratings of the rulemaking process, not on the specific ratings of the substantive qualities of the rules (such as efficiency and quality). Second, even with respect to the ratings for overall process, Langbein and Kerwin fail to control meaningfully for the effects of respondents' affiliations. They control for the ratings provided by respondents from different affiliations (e.g. business or environmental groups) relative to the ratings provided by respondents from EPA. See id. at 622-23 exhibs.8\&9. While ordinarily this would be fine, using EPA as the reference group in this case is problematic because Langbein and Kerwin have absolutely no EPA respondents in their conventional rulemaking sample. Hence, the most that could possibly be said is that Langbein and Kerwin have tested for how respondents from other affiliations, such as business and environmental groups, rate the process of both conventional and negotiated rules compared with the ratings EPA officials give just to negotiated rules. To rule out the effects of affiliation using the approach they take, Langbein and Kerwin would have needed to compare the ratings of nonEPA respondents in both types of rulemakings, with the ratings of EPA respondents in both types of rulemakings. As it stands, interpreting the results for the affiliation variables in Langbein and Kerwin's statistical model is a lot like trying to compare apples and oranges. In statistical terms, the excluded dummy variable in their model ("EPA") is essentially an interaction term, as all the ratings provided by EPA are interacting with the independent variable of interest ("reg neg"). The excluded dummy variable is effectively at work only for negotiated rules, not for conventional rules. Based on the available analysis provided by Langbein and Kerwin, it is therefore not possible to rule out the likelihood that the higher average ratings for negotiated rules that Harter points to are at least partly a function of the substantial differences in the affiliations of the respondents making up the two samples.

224 Langbein \& Kerwin, supra note 89, at 603. Langbein and Kerwin use the term "final rule" numerous times in their study to describe their data, even using it in their section heading on "Satisfaction with the Overall Process and the Final Rule." Id. at 602. Langbein and Freeman similarly state that "participants in negotiated rulemakings expressed greater satisfaction with the final rule than participants in conventional rulemakings." Freeman \& Langbein, supra note 133 , at 110. 
rulemaking - had not resulted in a final rule at the time of their interviews. ${ }^{225}$ This is significant because nineteen respondents in their study came from this one rulemaking, more than from any other rulemaking in their study except the reformulated gasoline rulemaking which had twenty respondents. 226 As a result, nearly twenty percent of the negotiated rulemaking respondents (nineteen out of 101) ${ }^{227}$ in the Langbein and Kerwin study could not express any meaningful satisfaction with the "eventual outcome (i.e., the final rule)" because EPA had simply not yet issued any final rule on hazardous waste manifests. ${ }^{228}$ Langbein and Kerwin nevertheless included responses from the participants in the hazardous waste manifest negotiations in their analysis. ${ }^{229}$

Putting these concerns to the side, it is conceivable that an appropriate comparison of participant perceptions of final rules might still result in higher average ratings for negotiated rules than for conventional rules. However, even if this were so, it would not provide "powerful" support, as Harter suggests, 230 for his belief that negotiated rulemaking leads to better rules. On the contrary, it would provide no reliable evidence at all for the underlying quality of the rules. To see why, consider Langbein and Kerwin's findings with respect to litigation. They asked their respondents to rate the likelihood that the rules for which they were involved in the rulemaking process would resist legal challenge. The average rating for negotiated rules (3.3) turned out to be significantly higher than the average rating given for conven-

225 Langbein \& Kerwin, supra note 89, at 629. According to Langbein and Kerwin, all of the other rules in their study had resulted in a final rule at the time of the interviews. Id. at 600.

226 Kerwin \& Langbein, Phase I, supra note 39, at 6.

227 Id.

228 Langbein \& Kerwin, supra note 89, at 603. Kenvin boasts that his study with Langbein provides "the most compelling evidence to date . . . that negotiated rulemaking produces . . . results superior to conventional rulemaking." Cornelius M. Kerivin, Rulenaking: How Government Agencies WrTE LAW AND MAKE Policy 182 (2d ed. 1999) (emphasis added) [hereinafter KERwIN 2d]. Yet the results had yet to come in for about twenty percent of his respondents in that study.

229 The number of responses included in the average ratings reported by Langbein and Kerwin range from ninety-five to ninety-nine for most of the criteria that they surveyed, indicating that they must have included responses from the interviews with the nineteen participants from the hazardous waste manifest rule. See Langbein \& Kerwin, supra note 89, at 604 exhib.1.

230 See supra note 202 and accompanying text. 
tional rules (1.9).231 Of course, this does not mean that negotiated rules really are more resistant to legal challenge. As we have seen, the evidence from court filings shows otherwise: negotiated rules are challenged at a higher rate than conventional rules. ${ }^{232}$ Along other dimensions, such as the average number of petitions filed and the rate of settlement, negotiated rulemaking exhibits no greater degree of resistance to litigation. ${ }^{233}$ It is precisely this kind of data, not data on participants' perceptions, that is needed to make judgments about the actual resistance of negotiated rules to legal challenge. Appropriately, Langbein and Kerwin acknowledge as much. ${ }^{234}$ Nowhere in their published article do they discuss the statistically significant and more favorable rating respondents give negotiated rules for their resistance to legal challenge. ${ }^{235}$ Instead, they make a limited effort to report the actual litigation rates for the rules included in their study. ${ }^{2.36}$ They admit "the limitations of the approach [they] used to determine the occurrence and outcomes of litigation."237 At best, they claim that "although our data are not as comprehensive as Coglianese's, our evidence is consistent with his."238

If participants in negotiated rulemakings tend to rate the resulting rules more favorably when it comes to litigation, they cer-

231 Langbein \& Kerwin, supra note 89, at 604 exhib.1. The ratings are on an 11-point scale, with a " 5 " indicating that the respondent believed the rule had the most resistance to legal challenge possible and a " 5 " indicating a belief that the rule had the least resistance possible.

232 See supra tbl.2.

233 Id.

234 Kerwin describes his study with Langbein as dealing with the issue of litigation "in only cursory fashion." KERwIN 2d, supra note 228, at 182.

235 In Table 3 of his article, Harter excerpts the average ratings given for resistance to litigation in the Langbein and Kerwin study, but, like Langbein and Kerwin, he makes no mention of them in the text of his article. Langbein \& Kerwin, supra note 89, at 604 exhib.1, cited in Harter, Assessing the Assessors, supra note 5, at 59 tbl.3.

236 Langbein \& Kerwin, supra note 89, at 614. Rather than consult court records, Langbein and Kerwin rely on information provided by ACUS on some of the challenges filed against negotiated rules and on simply asking their negotiated and conventional rulemaking respondents if they knew whether the rule in which they were involved had been challenged. Id. In the many interviews I have conducted with interest group lawyers and regulatory staff, I have often noticed that otherwise knowledgeable policy insiders do not always know about litigation challenging EPA rules, even for the rulemakings in which they have been involved.

237 Id.

238 Id. 
tainly may do so when it comes to other qualities of rules.239 Participants' perceptions of certain aspects of a final rule do not necessarily match reality. In fact, there are at least three wellaccepted psychological explanations for why participants' perceptions would tend to be more favorable toward negotiated rulemakings, none of which have anything to do with the underlying quality of the rules. Cognitive dissonance, the Hawthorne effect, and procedural justice theory all can lead one to expect that respondents would give higher ratings to negotiated rulemaking.

Social psychologists have for many years told us that individuals adjust their views to avoid dissonance because the existence of incompatible or dissonant cognitions is psychologically uncomfortable. ${ }^{240}$ One paradigmatic kind of cognitive dissonance, the so-called "effort justification paradigm," occurs as individuals respond to the effort needed to achieve an outcome.241 The more effort an individual must expend at some task, and the more unpleasant that effort, more dissonance is generated. ${ }^{242}$ Individuals who find themselves in such situations reduce dissonance "by exaggerating the desirability of the outcome." 243 In the classic study demonstrating this effect, women were asked to undertake either a severe or a mild rite of "initiation" to join a discussion group. ${ }^{244}$ Although the discussion group was equally boring in either case, the women who were assigned to undertake the more severe initiation evaluated the group more favorably than did the women who went through the mild initiation.245 As Elliot Aronson has explained, "going through hell and high water to gain admission to a boring discussion group was dissonant with

239 Indeed, if Langbein and Kerwin's analysis of litigation is "cursory," as Kerwin has acknowledged, see KERwiN 2d, supra note 228, at 182, it is hard to see how the application of the same research methods to other criteria could provide "the most compelling evidence to date that negotiated rulemaking produces, on many fronts, results superior to conventional rulemaking," as Kervin has claimed. Id.

240 See Leon Festinger, A Theory of Cognitive Dissonance 2-3 (1957).

241 Eddie Harmon-Jones \& Judson Mills, An Introduction to Cognitive Dissonance Theory and an Overview of Current Perspectives on the Theory, in CoGst. tive Dissonance: Progress on a Pivotal Theory in Social Psychology 3, 8 (Eddie Harmon-Jones \& Judson Mills eds., 1999).

242 Id. at 7.

243 Id.

244 Elliot Aronson \& Judson Mills, The Effect of Severity of Initiation on Liking for a Group, 59 J. ABNormal \& Soc. PsYCH. 177 (1959).

245 Id. at $180-81$. 
one's self-concept as a smart and reasonable person, who makes smart and reasonable decisions." 246

Negotiated rulemaking is similarly an effort-intensive form of rulemaking. Since participants in negotiated rulemaking expend more effort (and complain more of the need to expend more effort), ${ }^{247}$ we can expect that they will reduce their dissonance by viewing the outcome of this intensive process more favorably. What is striking from the Langbein and Kerwin study is that they find no statistically significant differences between the responses from the negotiated and the conventional rulemaking samples with regard to perceived net benefits from participation in the rulemaking process. ${ }^{248}$ The overwhelming majority of respondents in both groups found that the benefits they realized from their participation equaled or exceeded the costs. ${ }^{249}$ When the costs of participating in negotiated rulemaking are so much higher, individuals can be expected to exaggerate the desirable qualities of the outcome of the rulemaking process, holding this net satisfaction level constant and avoiding cognitive dissonance.

A second explanation for higher ratings by negotiated rulemaking participants may be found in the so-called Hawthorne effect. This effect, named for the factory in which it was first documented, refers to the artificial boost that occurs from the mere participation in an experiment or study. ${ }^{250}$ Researchers investigating the effects of changes in working conditions on productivity found that, over a period of more than two years, the productivity of the experimental group always rose-regardless of the changes made to the work schedule, lighting, methods of pay, and other conditions under study. ${ }^{251}$ The workers in the experimental group outperformed everyone else due to the high level of morale they associated with being in an experiment and because they knew they were being observed. ${ }^{252}$ Anyone who studies the perceptions of participants in negotiated rulemaking must be mindful that the Hawthorne effect may play a role be-

246 Elliot Aronson, Dissonance, Hypocrisy, and the Self-Concept, in CooniTIVE Dissonance, supra note 241, at 103, 112.

247 See supra note 139 and accompanying text.

248 Kerwin \& Langbein, supra note 217 , at 26, 45 tbl.38.

249 Id.

250 See F.J. Roethlisberger \& William J. Dickson, Management and the Worker (1939).

251 See id. at 75-89.

252 See id. at 85-86, 179-86. 
cause negotiated rulemaking is a novelty in the administrative process and has often been treated as an experiment.253 Those serving on a negotiated rulemaking may well be boosted in their morale or satisfaction just from knowing that they are participating in a special, experimental regulatory process. Philip Harter has himself earlier acknowledged that the Hawthorne effect can arise in cases of negotiated rulemaking. ${ }^{254}$

A final possible explanation for more favorable perceptions of negotiated rules stems from the work of social psychologist Tom Tyler and others on procedural justice.2ss The procedural justice literature supports the claim that how people value process independently of how they value outcomes. ${ }^{256}$ Langbein and her coauthors favor this theory, arguing that negoliated rulemaking fosters increased satisfaction, or a "warm glow," because participants are treated with respect and have a greater opportunity to provide their input.257 Of course, as already suggested, such a "warm glow" may also come in this case from cognitive dissonance, or perhaps from the Hawthorne effect, rather than from considerations of procedural justice. Indeed, it may well be that cognitive dissonance or the Hawthorne effect provide the better explanation, if for no other reason than that it is hard to see why negotiated rulemaking should be viewed as more procedurally legitimate than a full, open rulemaking process. Langbein and Kerwin never asked their respondents to rate the faimess of the rulemaking processes in which they participated, ${ }^{258}$ although they did ask them to rate the extent to which

253 See, e.g., USA Group Loan Servs., Inc. v. Riley, 82 F.3d 708, 714 (7th Cir. 1996) (describing negotiated rulemaking as a "novelty in the administrative process"). See also supra note 30 and accompanying text.

254 Philip J. Harter, EPA's Regulatory Negotiation Will Provide Opportunity' for Direct Participation in Development of a Regulation, 13 Envtl. L. Rep. (Envtl. L. Inst.) 10,202, 10,203 (July 1983) (noting the potential for "the intrusion of the Hawthome effect" in negotiated rulemaking).

255 See, e.g., E. Allan Lind \& Tom R. Tyler, The Social Psychology of Procedural Justice (1988).

256 See id. at 66-70.

257 Langbein \& Kerwin, supra note 89, at 626 (arguing that participants "care about how the authorities who make and implement rules and policies treat them (and others)"). See also Freeman \& Langbein, supra note 133, at 67 (asserting that "the data suggest that the legitimacy benefit turns, to a significant extent, on participation in a process, specifically one that presents an opportunity to affect the outcome").

258 Langbein \& Kerwin, supra note 89, at 626 (noting that "we did not ask respondents explicitly to rate the fairness of the rule-making process in which they participated"). 
public participation affected agency policy.259 As they write in their Phase II report, "in both cases [of negotiated and conventional rulemaking], public participation is viewed as open, unbiased, and influential. The two rulemaking processes are seen as equally receptive and responsive to public involvement." 260 If Langbein and Kerwin are correct that these two processes are equally responsive, ${ }^{261}$ then it would seem that researchers should look beyond procedural justice theory for an explanation of the "warm glow" allegedly fostered by negotiated rulemaking.

No matter which of these three theories best explains the more favorable ratings that participants might give to their experiences with negotiated rulemaking, the main point is that such perceptions do not provide a sound basis for drawing any inferences about the underlying efficacy and efficiency of regulations. Harter is simply wrong to claim that the results of the Langbein and Kerwin study show that negotiated rulemaking has succeeded in achieving better rules. ${ }^{262}$

\section{B. Alternative Forms of Rulemaking Offer Similar Advantages Without the Disadvantages of Decision Making by Consensus}

Harter not only misinterprets and overstates the results of the Langbein and Kerwin study, he also understates the problems engendered by negotiated rulemaking and the effectiveness of alternative forms of public participation in the rulemaking process. As a form of advocacy, it may be understandable for Harter to downplay the problems associated with negotiated rulemaking and to disregard the advantages of its alternatives. However, a complete assessment of negotiated rulemaking needs to take into account both advantages and disadvantages, and then to compare these against the performance of alternative forms of public participation in the regulatory process.

Although Harter does not acknowledge any problems with negotiated rulemaking, consensus-based processes actually present several potential limitations on the development of sound

259 Id. at 612.

260 Kerwin \& Langbein, Phase II, supra note 217, at 23-24.

261 Langbein \& Kerwin, supra note 89, at 613-14 (noting that "the agency is equally responsive to outside pressures in both rule making processes").

262 Harter, Assessing the Assessors, supra note 5, at 56. 
public policy.263 As explained earlier, negotiated rulemaking demands additional time and contributes new sources of conflict to the policy process. ${ }^{264}$ But the potential hazards of policy making by consensus run still deeper.

By emphasizing the attainment of consensus, negotiated rulemaking tends to lead agencies to focus on more tractable issues, rather than the most important problems or those most deserving of additional time and effort. That agencies select rules based on tractability is evident in, if nothing else, the paucity of rules that agencies have developed through negotiated rulemaking. ${ }^{265}$ Proponents of negotiated rulemaking have never claimed that consensus building would be appropriate for much more than about five to ten percent of all agency rulemakings, ${ }^{266}$ and in practice the use of the procedure has been still more rare. ${ }^{267}$ Agencies have eschewed negotiated rulemaking for federal rules having the broadest and most substantial impacts on industry and the public. ${ }^{268}$

An emphasis on consensus can lead not only to the selection at the outset of the more tractable policy issues for negotiation, but also to the selection of the more tractable issues within the negotiations themselves, even though these may not necessarily be the issues that are most important to the public. The fact that the negotiated rulemaking committee is charged with achieving consensus may inhibit some participants from raising important issues for fear of hindering the achievement of an agreement. In

263 For a more extensive discussion of the problems associated with decision making by consensus, see Coglianese, Is Consensus Appropriate?, supra note 2, at $106-13$.

264 See supra Parts II, III.

265 See supra note 27 and accompanying text.

266 See, e.g., Susskind \& Van Dam, supra note 1, at 44 (indicating that negotiated rulemaking "could be used to develop as much as ten percent of all rules"); Miller, supra note 1, at 21 (quoting EPA's Christopher Kirtz as stating that "between $5 \%$ and $10 \%$ of our regulations lend themselves to the technique of negotiated rulemaking").

267 Coglianese, Assessing Consensus, supra note 2, at 1277 (less than onetenth of one percent of all federal rules have been promulgated following a negotiated rulemaking proceeding).

268 Id. at 1318 (noting that "the EPA rules that affect the broadest number of organizations have never been selected for negotiated rulemaking"). Only five negotiated rulemakings have been classified as "major" or "significant" rules for having economic effects of $\$ 100$ million or more annually. Id. at 1314 n.266. Moreover, the Negotiated Rulemaking Act sets forth principles that agencies are supposed to use in selecting rules for negotiation, most of which place a premium on tractability rather than on policy importance. Id. at 1319-20. 
this way, a quest for consensus may exacerbate the tendency for "groupthink" to take hold.269 In the equipment leaks negotiated rulemaking, for example, an EPA official knew industry was overlooking issues related to an entire category of equipment in developing the rule, but never said a word about it during the negotiations. ${ }^{270}$ Only later, in the subsequent litigation over the rule, did the industry group raise the issue of coverage of the neglected equipment. 271 In many circumstances decision makers need conflict to help illuminate policy issues. The full articulation of opposing views, even structured in an adversarial process, may yield more useful information on which to construct public policy than a truncated discussion between individuals who are striving to achieve consensus. ${ }^{272}$

In addition to giving priority to tractable issues, negotiated rulemaking may encourage imprecision or ambiguity. ${ }^{273}$ Since it is usually easier to achieve consensus at higher levels of abstraction, the potential always exists that negotiators will adopt abstract or vague language. ${ }^{274}$ As Neil Kerwin has observed, when an agency commits itself to obtaining consensus, that is, "to pro-

269 When policy decisions are based on consensus some participants "may refrain from voicing their concerns, either by self-discipline and a desire not to shatter group harmony (suppression of doubts) or following direct hints by the leader (compliance) or by fellow group members (mindguards; peer pressure). When consensus is no longer required, group discussion can be more open." Paul 'T HART, Groupthink in Government: A STUdy of SMall Groups AND Policy Failure 293 (1994).

270 See Coglianese, Assessing Consensus, supra note 2, at 1307-1308 n.246.

271 Id. at 1305.

272 Cf. Roger B. Porter, Presidential Decision Making: The Eco. NOMIC POLICY BOARD 21-29 (1980) (describing the advantages of a "multiple advocacy" model of decision making, whereby presidential advisors are en. couraged to put forward competing positions as a means to achieve better informed policy).

273 See, e.g., Jane Mansbridge, Beyond Adversary Democracy 167 (1980). In her study of democratic decision making, Jane Mansbridge found that "[c]onsensual decision making also generates imprecision. In order to reach unanimous agreement, groups formulate their collective decision so as to blur potential disagreements." Id. This was demonstrated most clearly in recent years when former EPA Administrator William Ruckelshaus convened a set of negotiations between industry, government, and the environmental community to forge a consensus about how to improve environmental policy in the United States. The resulting agreement consisted largely of vague statements and platitudes. See Cary Coglianese, The Limits of Consensus, ENvironment, Apr. 1999, at 28.

274 See Colin Diver, The Optimal Precision of Administrative Rules, 93 YAle L.J. 65, 75 (1983). 
ducing a rule with which everyone with a recognized interest can agree, the only way to break certain deadlocks is to produce a rule that ignores unresolved (or unresolvable) issues or deals with them through vague language whose meaning will be disputed during the implementation process."275 Adopting vague language may serve to secure agreement for its own sake, but doing so can constrain the effectiveness of any resulting public policy.

Negotiated rulemaking's emphasis on unanimity also makes it more likely that the final outcome will succumb to the lowestcommon-denominator problem. The outcome that is minimally acceptable to all the members of a negotiated rulemaking committee will not necessarily be optimal or effective in terms of achieving social goals. A recent study of negotiated rulemaking conducted by Charles Caldart and Nicholas Ashford shows that in industries that are not likely to innovate in the absence of strong governmental regulation, the lowest-common-denominator problem keeps negotiated rules from promoting the technological innovation needed to improve environmental and safety performance. ${ }^{276}$ They conclude that because industry representatives in these types of industries will be reluctant to agree to regulations that would compel firms to make dramatic investments in new technologies, "negotiated rulemaking's focus on consensus can effectively -remove the potential to spur innovation."277

Although these problems do not necessarily arise in every negotiated rulemaking, and some can surely occur even in certain conventional rulemakings, a complete assessment of negotiated rulemaking needs to take these potential hazards into account. The incentives created by a search for consensus tend to make these problems particularly more acute in regulatory negotiations. Moreover, a complete assessment of negotiated rulemaking and the quality of regulatory policy must compare negotiated rulemaking with alternative forms of policy deliberation that do not aim for unanimity. Although advocates of negotiated rulemaking claim otherwise, it is possible to achieve many of the

275 KERWIN 2d, supra note 228, at 109.

276 Charles C. Caldart \& Nicholas A. Ashford, Negotiation as a Means of Developing and Implementing Environmental and Occupational Health and Safety Policy, 23 HaRv. ENvTL. L. REv. 141 (1999).

$2 \pi 7$ Id. at 201. 
asserted advantages of negotiated rulemaking by expanding participation in the conventional rulemaking process, all without creating the perverse incentives that can arise when policymakers seek consensus.

The choice for agencies is not between developing rules through negotiated rulemaking or developing rules inside a closet. Agencies can, and regularly do, engage the interests affected by rules through individual and collective forms of dialogue. ${ }^{278}$ These alternative forms of deliberation, be they individual meetings, public workshops, or formal advisory committees, provide the agency with the same kinds of opportunities for public input into regulatory decision making as negotiated rulemaking. ${ }^{279}$ But they also avoid creating pressures to emphasize tractability, accept ambiguity, or descend to the lowest common denominator. After all, it is the deliberation-not the consensus-that generates the information that enables agencies to craft their policy decisions. To the extent that public officials already employ participatory processes that enable interested parties to share information, these alternative forums for deliberation within the conventional rulemaking process can provide comparable, if not superior, results.

Harter and other proponents of negotiated rulemaking question whether anything short of negotiated rulemaking will do. ${ }^{280}$ Harter specifically lauds the averaging approach EPA adopted in its reformulated gasoline regulation as a key innova-

278 See Coglianese, Assessing Consensus, supra note 2, at 1330-31.

279 In their Phase II report, Langbein and Kerwin indicate that their respondents view the EPA as equally responsive to public input during the conventional rulemaking process:

Conventional rulemaking respondents view EPA as open to their ideas and the rules the Agency produces as heavily influenced by the public participation that does occur. While negotiated rulemaking may offer slightly greater benefits in terms of the efficacy of public participation, they are properly viewed at best as incremental given the solid base of public involvement that appears to have been established by EPA's overall approach to rulemaking.

Kerwin \& Langbein, Phase II, supra note 217, at 24.

280 See, e.g., Harter, Fear of Commitment, supra note 5, at 1410-11, 1418-19 (arguing that consultative processes other than negotiated rulemaking fail to achieve as many benefits); Freeman \& Langbein, supra note 133, at 64, 134 (expressing doubt that policy deliberations short of negotiated rulemaking will work as effectively). See also KERwIN 2d, supra note 228, at 183 (observing that "advocates of negotiated rulemaking are skeptical of partial substitutes and decry the loss of commitment that goes with them"). Although advocates continue to claim that nothing short of negotiated rulemaking will work effectively, 
tion that was discovered only because the rule was negotiated. ${ }^{281}$ Under the averaging approach, refiners could meet fuel standards based on the average applied over entire stocks of fuel refined during the calendar year rather than applied on a per gallon basis. ${ }^{282}$ In return for the additional flexibility that this averaging approach provided to refiners, the final rule required refiners to meet a standard that was somewhat more stringent, thus satisfying environmentalists' concerns. ${ }^{283}$ Harter argues that

no research has yet systematically to compare negotiated rulemaking with other intensive but non-consensual efforts at public deliberation.

281 See Harter, Assessing the Assessors, supra note 5, at 50 (asserting that "[t]he fact that the rule had been negotiated ... resulted in a much better rule"). For the text of the reformulated gasoline rule, see Regulation of Fuels and Fuel Additives; Standards for Reformulated and Conventional Gasoline, 59 Fed. Reg. 7716 (Feb. 16, 1994) (to be codified at 40 C.F.R. Part 80). Ed Weber calls the effort leading to the promulgation of the reformulated gasoline rule a "new model for regulation that can achieve more effective environmental results at lower costs than associated with the adversarial approach." Edward P. Weber, Successful Collaboration: Negotiating Effective Regulations, Evviron: MENT, Nov. 1998, at 10,11. In reality EPA's reformulated gasoline rule has been one of EPA's most problematic regulations in recent years. Not only did the rule result in several administrative and legal challenges, it also generated exceptional outcry in the press and led to the first WTO decision striking down a U.S. regulation. See Coglianese, Assessing Consensus, supra note 2 at 1292; World Trade Organization, Doc. No. WT/DS2R, reprinted in World Trade Organization: Report of Panel in United States-Standards for Gasoline, 35 I.L.M. 274, 279-91 (1996). In addition, the fuel additive authorized by the rule, MTBE, has generated enormous controversy as it may be a carcinogen. The possibility that MTBE may enter drinking water if leaked into groundwater in various parts of the country has prompted efforts to ban the future use of the additive. See, e.g., Marla Cone, EPA to Ban Gas Additive Nationside, L.A. TIMEs, Mar. 21, 2000, at A3; Marla Cone, Elimination of Additive from Gas is Ordered, L.A. TMmes, Dec. 10, 1999, at A3. See also Judith Newman, Tisenty of the Greatest Blunders in Science in the Last Twenty Years, Discover, Oct. 2000, at 78, 83. At the same time that Harter claims that certain purportedly beneficial aspects of the rule ought to be attributed to negotiated rulemaking, he also disavows any connection between negotiated rulemaking and the problems of the rule. See Harter, Assessing the Assessors, supra note 5, at 50. However, it is certainly plausible that a more adversarial process could have resulted in a more meaningful airing up front of concerns about MTBE and the impact of the rule on foreign refiners, and that the EPA might well have been more receptive to these concerns. Nevertheless, even if Harter were correct that negotiated rulemaking did not cause the problems with the reformulated gasoline rule, neither did it prevent them. Regulatory negotiation did not cure the malaise in this rulemaking.

282 Standards for Reformulated and Conventional Gasoline, 59 Fed. Reg. at 7721, 7724, 7753-54, 7756-57.

283 Standards for Reformulated and Conventional Gasoline, 59 Fed. Reg. at 7721. See also Standards for Reformulated and Conventional Gasoline, 57 Fed. Reg. 13,416, 13,425 (Apr. 16, 1992) (supplemental notice of proposed rulemak:- 
this averaging provision, combined with the somewhat more stringent standard, was a significant innovation that EPA would not have developed had it not been engaged in a negotiated rulemaking. ${ }^{284}$

EPA officials, though, did not need negotiated rulemaking in order to conceive and adopt such an averaging plan. EPA had already adopted high-profile emissions trading policies more than a decade before the reformulated gasoline rule, all of which rely on averaging, but none of which grew out of negotiated rulemakings. ${ }^{285}$ More specifically, EPA's fuel standards relied on averaging approaches since at least the 1970s, and averaging was integral to the EPA's program for phasing out leaded gasoline in the 1980 s. $^{286}$ Moreover, regulators at EPA hardly needed formal negotiations to tell them that environmental groups would more readily support an averaging approach if it was accompanied by more stringent standards. Indeed, EPA had made the same kind of trade-off in allowing emissions trading and banking for heavyduty diesel engines, with a corresponding twenty percent reduction in standards, four years before its reformulated gasoline

ing) (describing the more stringent standards for averaging with the per-gallon standards).

284 Harter first advanced this argument in remarks delivered at a panel organized around my research at the Association of American Law Schools meeting on January 9, 1998. See supra note 85 . He repeats in his recent article essentially the same claims about the averaging component of the reformulated gasoline rule which he made at the AALS meeting. Harter, Assessing the Assessors, supra note 5, at $50 \mathrm{n} .96$ (asserting that the eventual rule resulted in lower standards and greater flexibility "than would have emerged from a traditional rulemaking").

285 For a review of emissions trading and other market-based policies, see Robert W. Hahn \& Robert N. Stavins, Incentive-Based Environmental Regulation: A New Era From an Old Idea, 18 Ecology L.Q. 1 (1991). Administrative lawyers will be quite familiar with emissions averaging, as such an approach undergirded the EPA's emissions trading rule which was challenged in Chevron, USA, Inc. v. Natural Resources Defense Council, 467 U.S. 837 (1984), reh'g denied, 468 U.S. 1227 (1984).

286 Robert Hahn \& Gordon Hester, Marketable Permits: Lessons for Theory and Practice, 16 Ecology L. Q. 374 (1989) (describing lead-trading rule's provisions allowing refiners to add more lead to gasoline during certain parts of the year and less in others in order to arrive at a lead level consistent with their yearly allowable permits). See also Standards for Reformulated and Conventional Gasoline, 59 Fed. Reg. at 7768 ("Lead phasedown was similar to reformulated gasoline in that refiners and importers were required to meet an average standard that applied to gasoline produced or imported."). 
rulemaking. ${ }^{287}$ In all of these earlier cases, EPA officials developed the same kind of innovation Harter attributes to negotiated rulemaking, but they did so using conventional rulemaking procedures.

The more widely used forms of public participation in conventional rulemaking offer regulators the same opportunity to incorporate the knowledge and practical experience of the public into regulatory decisions-an opportunity that advocates claim uniquely for negotiated rulemaking. However, using these alternative forms of public participation in conventional rulemaking can improve regulatory policy while minimizing the problems that arise when consensus becomes the goal for regulatory policy, as occurs in negotiated rulemaking. The validity of my conclusion in Assessing Consensus remains undiminished: in the absence of negotiated rulemaking's promised benefits, "agencies" continued reliance on public participation methods which do not depend on consensus would appear the more sensible approach to making regulatory decisions."288

\section{CONCLUSION}

For years, advocates of negotiated rulemaking have put forth enthusiastic promises about how negotiated rulemaking would reduce litigation and shorten the rulemaking process. Philip Harter, in his recent article purporting to assess my empirical study, has continued this line of advocacy for negotiated rulemaking. He advances a series of criticisms of my research but, as I have explained in this Article, he is simply wrong about each of them and about each of the claims he makes in his defense of negotiated rulemaking. His continued efforts to make a case for negotiated rulemaking fail to adhere to the most rudimentary principles of sound empirical analysis, including the use of clear criteria, consistency in applying these criteria to both treatment and comparison groups, and the inclusion of negative as well as positive cases in an empirical evaluation. In effect, Harter puts a thumb down on the side of the scale that favors negotiated rulemaking, offering a perhaps predictable plea of ad-

287 See Certification Programs for Banking \& Trading of Oxides of Nitrogen \& Particulate Emission Credits for Heavy Duty Engines, 55 Fed. Reg. 30,584, 30,585 (July 26, 1990) (to be codified at 40 C.F.R pt. 86).

288 Coglianese, Assessing Consensus, supra note 5, at 1336. 
vocacy but not any credible new assessment of negotiated rulemaking.

Despite nearly twenty years of experimentation, negotiated rulemaking has yet to achieve a demonstrable reduction in the time it takes to develop regulations nor in the frequency or intensity of subsequent litigation over those regulations. Indeed, the empirical record shows that negotiated rulemaking actually demands more effort and results in more litigation than other comparable rulemaking processes. Had it not been for several decades worth of enthusiastic advocacy of negotiated rulemaking, these results would probably neither be surprising nor contested. After all, it is bound to take an intensive effort to develop a consensus among multiple interests on a proposed rule, even for those rules that agencies find more predisposed to success and which are for that reason selected for negotiation in the first place. It is similarly unrealistic to expect that negotiation will stave off subsequent litigation, especially when negotiated processes themselves raise expectations and generate conflicts over who participates in the negotiation and over what the terms (and silences) in the negotiated agreements mean.

The finding that negotiated rulemaking neither reduces rulemaking time nor prevents litigation could conceivably be viewed as somewhat less of a failure if it could be shown that negotiated rulemaking systematically led to significantly better quality rules. Harter makes such an assertion, but it too is unsupported by the available body of empirical research. The results of the Langbein and Kerwin study cited by Harter are not easy to interpret, but at best they can be said to show only that participants in negotiated rulemakings tend to perceive the conventional rulemaking process in terms better than those who file comments perceive the conventional rulemaking process. Perceptions on the part of participants in negotiated rulemaking, formed as they are after involvement in quite intensive processes, are likely explained by factors other than genuine, underlying policy improvements. Indeed, there are good reasons to doubt that negotiated rulemaking will in fact lead to any systematic improvement at all in regulatory policy. Making consensus a precondition for policymaking will only likely exacerbate problems such as ambiguity, lowest common denominator results, and an undue emphasis on tractability. More significantly, whatever benefits negotiated rulemaking might presumably hold in terms 
of generating information and dialogue over regulatory policy, these benefits appear to be just as achievable through alternative processes that encourage public participation but which do not demand consensus. Negotiated rulemaking's failure to achieve its goals of reducing rulemaking time and preventing litigation is simply not offset by any demonstrated improvements in the quality of regulatory policy when compared with other ways of developing regulations.

Given that the promises made for negotiated rulemaking over the years remain unfulflled, agency officials seeking to involve the public in the rulemaking process should continue to rely on other processes for developing regulations. Negotiated rulemaking demands a concentrated investment of time and resources by all involved, but without any clear corresponding return in terms of avoiding litigation or achieving other goals. Nothing in Harter's latest effort to salvage negotiated rulemaking diminishes this conclusion. Agency officials, legislators, and other observers of the regulatory process would do well to look elsewhere for a cure to whatever ills the regulatory process. 